\title{
EL JINETE QUE REGRESÓ A LUCENTUM. UN LÁGYNOS IBÉRICO DECORADO DEL TOSSAL DE MANISES (ALICANTE)
}

\author{
THE RIDER THAT RETURNED TO LUCENTUM. AN IBERIAN DECORATED LÁGYNOS FROM EL \\ TOSSAL DE MANISES (ALICANTE)
}

ENRIC VERDÚ PARRA

Museo Arqueológico de Alicante-MARQ everdu@diputacionalicante.es http://orcid.org/0000-0002-6323-5304

Recepción: 17-05-2017

Aceptación: 29-08-2017

\section{Resumen}

La reciente identificación de un lágynos ibérico procedente de las excavaciones antiguas en la ciudad romana de Lucentum (el Tossal de Manises, Alicante), ha permitido practicar un meticuloso análisis iconográfico de su rica decoración, posibilitando además un intento de contextualización arqueológica.

Palabras clave. Lágynos; cerámica ibérica decorada; jinete; romanización; Tossal de Manises.

\begin{abstract}
The recent identification of an Iberian lágynos, recovered in old excavations in the Roman city of Lucentum (el Tossal de Manises, Alicante), has allowed a meticulous iconographic analysis of its rich decoration. Thanks to this analysis, an archaeological contextualization has been suggested.
\end{abstract}

Key words. Lágynos; decorated Iberian pottery; rider; romanization; Tossal de Manises. 


\section{APUNTES HISTORIOGRÁFICOS}

Como ya avanzábamos en una publicación anterior (Verdú y Olcina, 2012), durante largo tiempo se atribuyó una procedencia errónea a un interesante fragmento cerámico conservado en el Museo Arqueológico de Alicante-MARQ. La pieza ya aparece fotografiada en el trabajo clásico Museo Arqueológico Provincial de Alicante. Catálogo-guía (Lafuente,
1959: lám. XVI) (Fig. 1A), junto a otras cerámicas expuestas en el primitivo Museo. Es posible que ya desde un primer momento se extraviase la información sobre su procedencia, asociándose a partir de entonces el fragmento con el poblado ibérico de Castillo del Río (Aspe) ${ }^{1}$.

Sin embargo, fruto de los trabajos de revisión de los fondos de dicha institución, en el año 2003 fue identificado un pequeño fragmento que unía con la
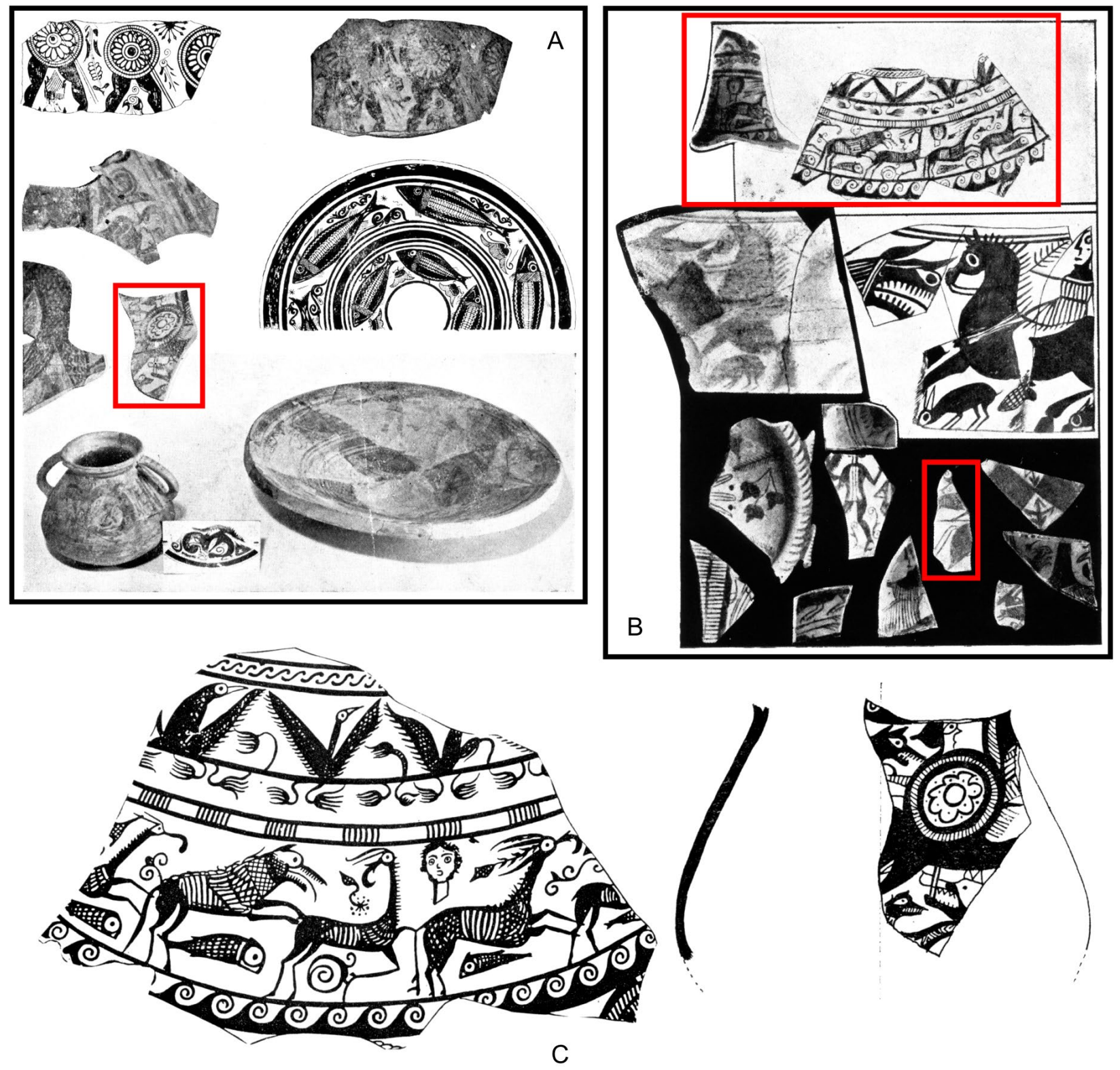

Figura 1: A y B. Fotografías de cerámicas ibéricas con decoración figurada del Museo Arqueológico de Alicante entre las que se identifican los fragmentos analizados (Lafuente, 1959: láms. XVI y XVII). C. Desarrollo de la decoración de las piezas estudiadas (Llobregat, 1972: figs. 106 y 108).

\footnotetext{
1. Así lo consideran Llobregat (1972: fig. 108), Nordström (1973: 163-164, lám. 22, nº 3), González (1975: 697-700) o Pericot (1979: fig. 81). Esta misma atribución consta en numerosos estudios posteriores (Maestro, 1989: 251-252, fig. 89; Azuar, 1994: 21; Quesada, 1997: lám. XVIA; Tortosa, 2006: 103-104, nº 1; García Gandía, 2008: 90 ss., fig. 46, etc.).
} 

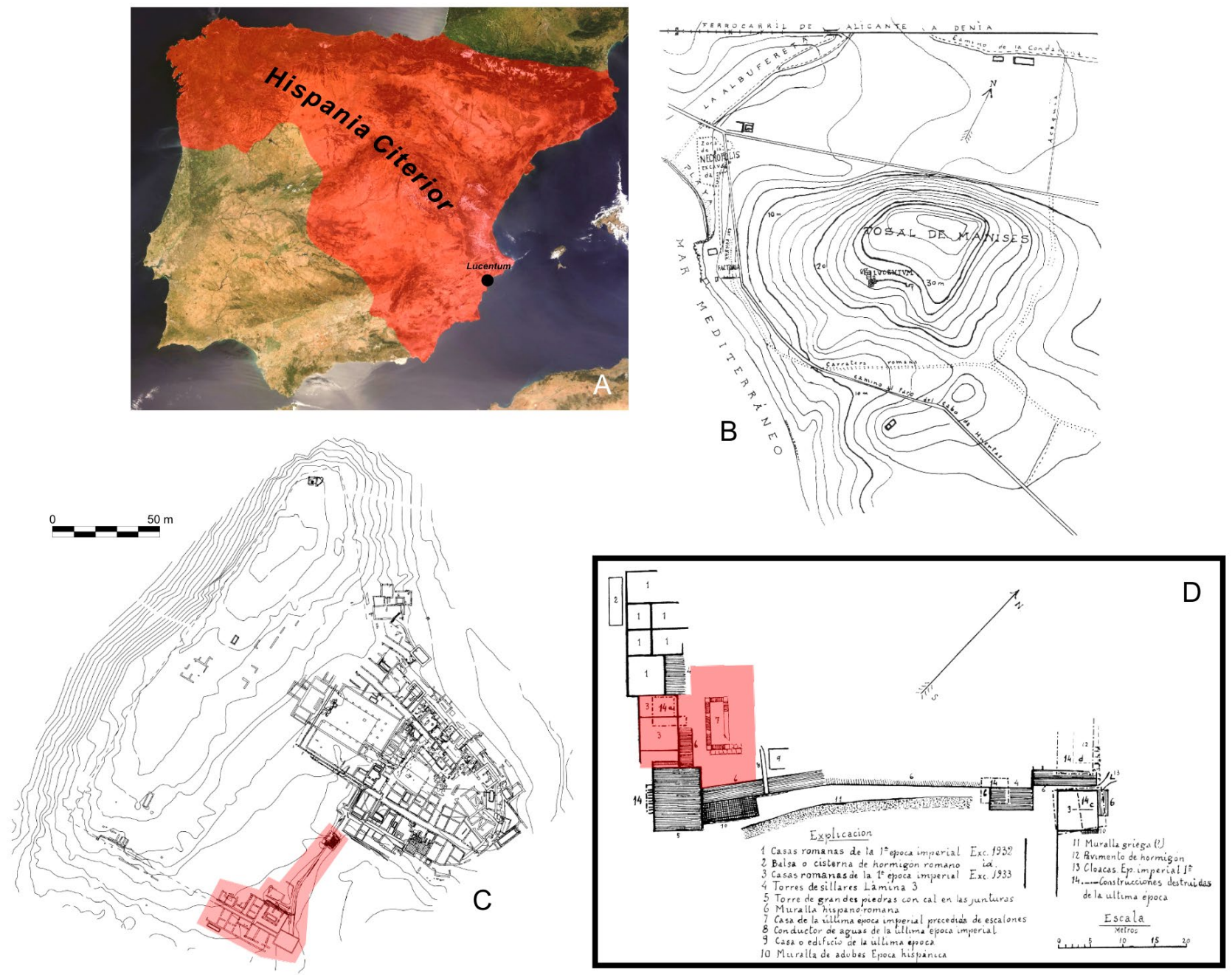

Figura 2: A. Localización de la ciudad de Lucentum (el Tossal de Manises, Alicante). B. Plano original del Tossal de Manises (Lafuente, 1934: lám. XXII, $n^{\circ}$ 1). C. Planta actualizada con indicación del área excavada por J. Lafuente. D. Perímetro aproximado de la «domus del peristilo» (a partir de Lafuente, 1934: lám. XXII, nº 2).

pieza anterior, el cual conservaba la signatura TM5398, confirmando su correspondencia con el Tossal de Manises, la romana Lucentum. Lafuente había publicado este segundo fragmento junto a otros materiales recuperados durante las excavaciones llevadas a cabo entre los años 1931 y 1933 (Lafuente, 1957: 96, lám. XV; 1959: lám. XVII) (Fig. 1B). A finales del 2011 se localizó un tercer fragmento, siglado esta vez con el código TM-5396, aunque el hallazgo más revelador aconteció un año después, al unir el conjunto con el cuello de cerámica TM-5393, catalogado durante décadas como un «timiaterio» $»^{2}$, no existiendo duda

2. Entre otras referencias destacan las de Lafuente (1932: 34 35, fotos 23, no 14 y 24; 1934: lám. XVII, II; 1944: 81-82, fig. 30; 1959: lám. XVII), Cabré (1934: 367), Figueras (1940: 179), Fernández de Avilés (1944: 162-163, fig. 1, láms. I y II, $n^{\circ} 1$ ), García y Bellido (1944: 116, fig. 36), Beltrán (1967: 241), Llobregat (1972: fig. 106), Nordström (1973: lám. 13, $\mathrm{n}^{\circ} 1$ y 2), Maestro (1989: 285-287, fig. 104; 2013-14: 86), Tiemblo (1999: 182-183 y 190, fig. 20), Santos (2004: fig. 133), Tortosa (2006: $n^{\circ} 141$, lám. 39), etc. alguna de su atribución al yacimiento alicantino ${ }^{3}$ (Fig. 1C).

Conocemos las áreas del yacimiento exhumadas por José Lafuente gracias a someras descripciones, algunas fotografías (Lafuente, 1932: 12 y 23 ss., fotos 3, 15, 16 y 29-30; 1934: 33 ss., láms. II-IV y XIII-XIV) y a una rudimentaria planimetría en la que se indican los hallazgos efectuados hasta 1933 (Fig. 2B y 2C). En otra planta (Lafuente, 1934: lám. XXII, nº 2) (Fig. 2D) es posible distinguir varias construcciones que considera de cronología imperial, entre ellas la muralla con sus torres y algunas estancias domésticas, así como una especie de aljibe rectangular de hormigón que formaría parte del peristilo de una domus. De entre las ruinas se recuperaron ánforas, vajilla campaniense y

3. Este hecho ya aparece aceptado en la tesis doctoral de M. Pérez Blasco (2014: 845-846, fig. 202, n 16), en la monografía sobre la fauna ibérica coordinada por C. Mata (2014: 177, fig. 291), así como en la reciente publicación sobre el poblamiento ibérico de Aspe (Moratalla, 2015: 115, fig. 3). 
con «adorno de relieve», lucernas y cerámicas ibéricas decoradas con «representaciones de flora, fauna y del hombre», que Lafuente antepone cronológicamente a las aretinas y primeras sigillatas y fecha en pleno siglo I a. C. (Lafuente, 1932: 27; 1934: 41 y 44). Sobresale en este conjunto un fragmento con una escena de caza ${ }^{4}$ que se corresponde con el cuello cerámico anteriormente referido.

El sector excavado por Lafuente se enclava en el extremo meridional del Tossal de Manises, concretamente en el ángulo sur del segundo sistema de fortificación, cuya construcción data de un momento avanzado del primer cuarto del siglo I a. C. Comprende además el espacio adjunto de la muralla, donde destaca al interior la denominada «domus del peristilo», de cronología plenamente augustea, que abarcaría unos $400 \mathrm{~m}^{2}$ y pudo pertenecer a una familia de cierto rango socio-económico (Olcina y Pérez, 1998: 80-81; Olcina, 2009b: 106-108; Olcina et al., 2015a: 258).

\section{FORMA Y DECORACIÓN DE UN VASO SINGULAR}

Disponemos de una parte más que significativa del $\operatorname{vaso}^{5}$ (Fig. 3), pese a no alcanzar el perfil completo y faltar todo el borde y el tercio inferior. La pasta es fina y compacta, color naranja pálido, con desgrasante mineral minúsculo y diminutas vacuolas en superficie. Al interior se observan acanaladuras horizontales paralelas provocadas por el torneado.

La pieza consta de un largo cuello de perfil hiperboloide muy estilizado, cuyo borde pudo ser circular, moldurado hacia el exterior y con un pequeño escalón interno, y el arranque de un cuerpo que debió contar con un desarrollo globular o lenticular. Se aprecia además el inicio de un asa en el extremo superior. A partir de todas estas características es posible catalogarla como un lágynos ${ }^{6}$, que pudo alcanzar unos $25 \mathrm{~cm}$ de altura (Fig. 3D). Se trata de un tipo inédito dentro del repertorio cerámico registrado en el Tossal de Manises, derivado de un modelo encuadrable entre el siglo III a. C. y época augustea.

4. «...cacería de cabras salvajes, una de las cuales lleva clavado un arpón, por hombres representados por cabezas y un perro que acomete a una de ellas; en el cielo las águilas y en el mar los peces, que quizá solo se han pintado, como otros adornos, por horror al vacio, es decir, porque no quede espacio libre») (Lafuente, 1932: 34-35).

5. Conserva unos 14'6 cm de altura, con un ancho máximo de $21 \mathrm{~cm}$.

6. Con el concepto de lágynos/lagoena nos referimos a una especie de botella o jarro de cuello alto y estrecho, con asa vertical, cuerpo ancho, globular o panzudo, habitualmente con marcada carena, utilizándose seguramente para contener y servir vino en banquetes o sympósia durante la época helenística (Pierobon-Benoit, 1979; Pérez Ballester, 1994: 348; Cabrera, 2004b: 8-9; Huguet y Ribera, 2013: 198-199).
Uno de estos lágynoi se halló en Libisosa (Lezuza, Albacete) (Uroz, 2012: 264, fig. 208a), así como también otro con engobe blanco y decoración pintada ${ }^{7}$ (Uroz, 2012: 273-274 y 298, fig. 213; Uroz y Uroz, 2014: 203-204, figs. 7 y 8c) (Fig. 4A), ambos con unas dimensiones muy similares al ejemplar alicantino. Estas piezas, relacionadas con la importación de vino griego, se fabricaron en fechas más tardías sin engobe o barniz, integrándose en el servicio de mesa habitual y participando del fenómeno generalizado de fabricación de imitaciones entre mediados del siglo II a. C. y el período julio-claudio (Principal, 2008: 127).

Jarras con cuello largo y estrecho y cuerpo bicónico con carena alta se documentan en la Tarraco tardorrepublicana, destacando un modelo también similar a la pieza de Lucentum (Díaz, 2000: 224, fig. 39, no 2) (Fig. 4B). La forma evoca el tipo romano de lagoena Vegas 38/Lattara CL-REC 3d, con una cronología genérica del II a. C. al I d. C. (Vegas, 1973: 92, fig. 31, no 1; Beltrán, 1990: 194, fig. 96, no 875; Py, 1993 : 222 y 223), como ocurre en el pecio de Escombreras (Cartagena) (VV.AA., 2004: 169 y 197, nº 45 y 110) (Fig. 4C). Estas botellas con asa se documentan sobre todo a partir de época augustea, como sucede en el noreste peninsular (Casas et al., 1990: 130-134; 1995: 122, fig. 14) (Fig. 4D) caso de Ampurias (Aquilué et al., 1984: 409, fig. 137; 2010: 45, fig. 19, no 8) (Fig. $4 \mathrm{E})$. Por otro lado, el esbelto perfil del cuello recuerda la forma de los portalucernas ibéricos localizados en Cabezo de Alcalá de Azaila (Teruel) (Cabré, 1944: 8689, fig. 87, láms. 57-58; Beltrán, 1967: 239-241, figs. 62-63) (Fig. 4F), en ocasiones con frisos con postas y series de SSS. Podría considerarse este modelo como precedente del tipo romano de botella de «tradición indígena» Abascal 6 (Fig. 4G), clara reminiscencia del lékythos griego, registrándose tanto en la Meseta norte como en el valle del Ebro durante el siglo I d. C. (Abascal, 1986: 67-68, figs. 48-54; 2008: 434; Beltrán, 1990: 161, fig. 78, nº 699).

En los niveles tardorrepublicanos y altoimperiales de Lucentum se han localizado imitaciones de vajilla romana de mesa, evidenciando destacadas similitudes con los repertorios de Ilici (l'Alcúdia d'Elx). Cabe citar al respecto la aparición de cerámicas de imitación de tradición ibérica, con cocción oxidante y pastas de buena calidad, en ocasiones con decoración figurada (Sala et al., 2007: 134-136, fig. 3; Principal, 2008: 134, fig. 6C.2). Este hecho corrobora el peso inicial del factor indígena en ambos emplazamientos, donde debió residir un contingente de población junto a los colonos, posibilitando una coexistencia entre vajillas

7. Estas cerámicas, que parecen tener su origen en Asia Menor, se registran ocasionalmente en el Mediterráneo occidental, como sucede en Carthago Noua, Empórion o l'Alcúdia (Cabrera y Pérez, 1980; Pérez Ballester, 1985: 143 y 145, fig. 1, $n^{0} 1-3$; 1994: 350-351; 2012: 73-75, fig. 18), pudiéndose fechar entre mediados del siglo II a. C. y el siguiente (Cabrera, 2004a: 65-67, fig. 43; 2004b: 5). 

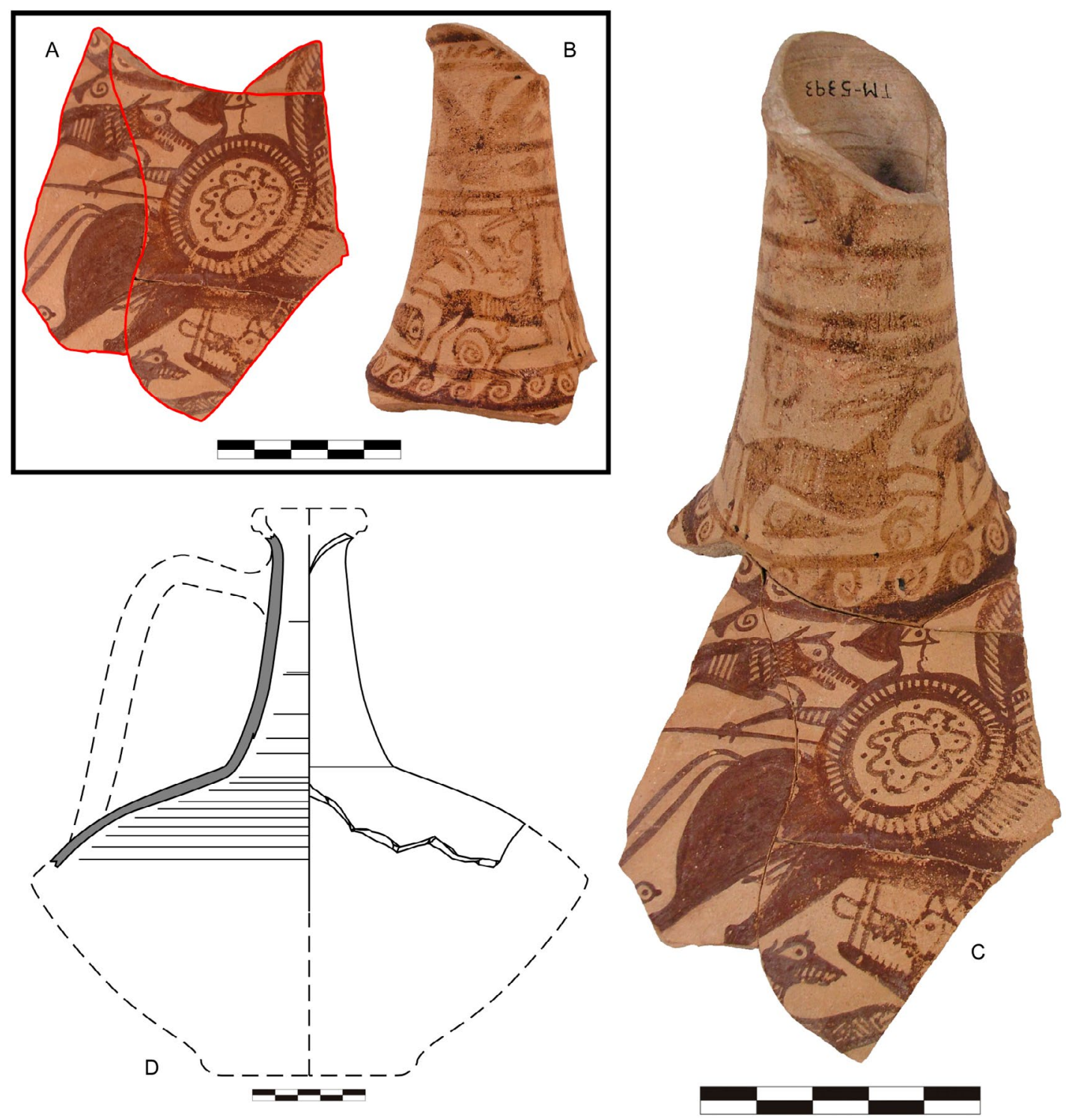

Figura 3: A. Fragmento original con jinete una vez añadidos los fragmentos TM-5398 y TM-5396. B. Cuello cerámico decorado TM5393. C. Pieza completa tras su restauración (CS 3005). Fotos Archivo Gráfico MARQ. D. Propuesta de reconstrucción de la forma del lágynos del Tossal de Manises.

ibéricas y romanas, entre las cuales pudo producirse un fenómeno de asimilación, sincretismo o mestizaje en busca quizás de atraer a los nuevos compradores (Abascal, 2008: 429; Ronda y Tendero, 2010: 322330; 2014: 193 ss.; Tendero et al., 2014: 231 y 234). Por otra parte, buena muestra de la perduración de los usos y costumbres alfareras indígenas en el Tossal de Manises es la presencia de grandes contenedores, urnas, lebétes, kálathoi, olpes, cubiletes y platos, vasos pintados con motivos propios del denominado «estilo Elx-Archena» (Guilabert et al., 2010: 348-350, fig. 9, $\left.\mathrm{n}^{\mathrm{o}} 1-5\right)$. En la Valentia sertoriana la cerámica ibérica continúa siendo relativamente abundante y no presenta cambios tipológicos sustanciales con respecto al siglo II a. C., si bien se prefieren las jarras romanas para el servicio de líquidos (Ribera, 2014: 75-76). La producción cerámica en Ilici tampoco retrocede en absoluto sino que se adapta y reinventa para la nueva población y quizás también para una supuesta población preexistente, ahora romanizada. Los talleres ilicitanos de la primera mitad del siglo I a. C. se definen, entre otros factores, por la fabricación de imitaciones de vasos metálicos y de paredes finas romanos, recurriendo, sin embargo, a la tradicional decoración figurada (Ronda y Tendero, 2014: 191-194; 2015: 262-263; Tendero y Ronda, 2014: 223-224).

Tan interesante como sus peculiaridades morfológicas es el elaborado repertorio decorativo de que el lágynos de Lucentum hace gala, plasmado sobre la superficie externa del recipiente con pintura rojo oscuro, mucho más tenue en toda la zona del cuello debido a la erosión y en mejor estado en el arranque del cuerpo (Fig. 5).

La composición se estructura en torno a dos frisos horizontales en el cuello, el superior delimitado mediante una cenefa de diminutas SSS entre dos bandas 


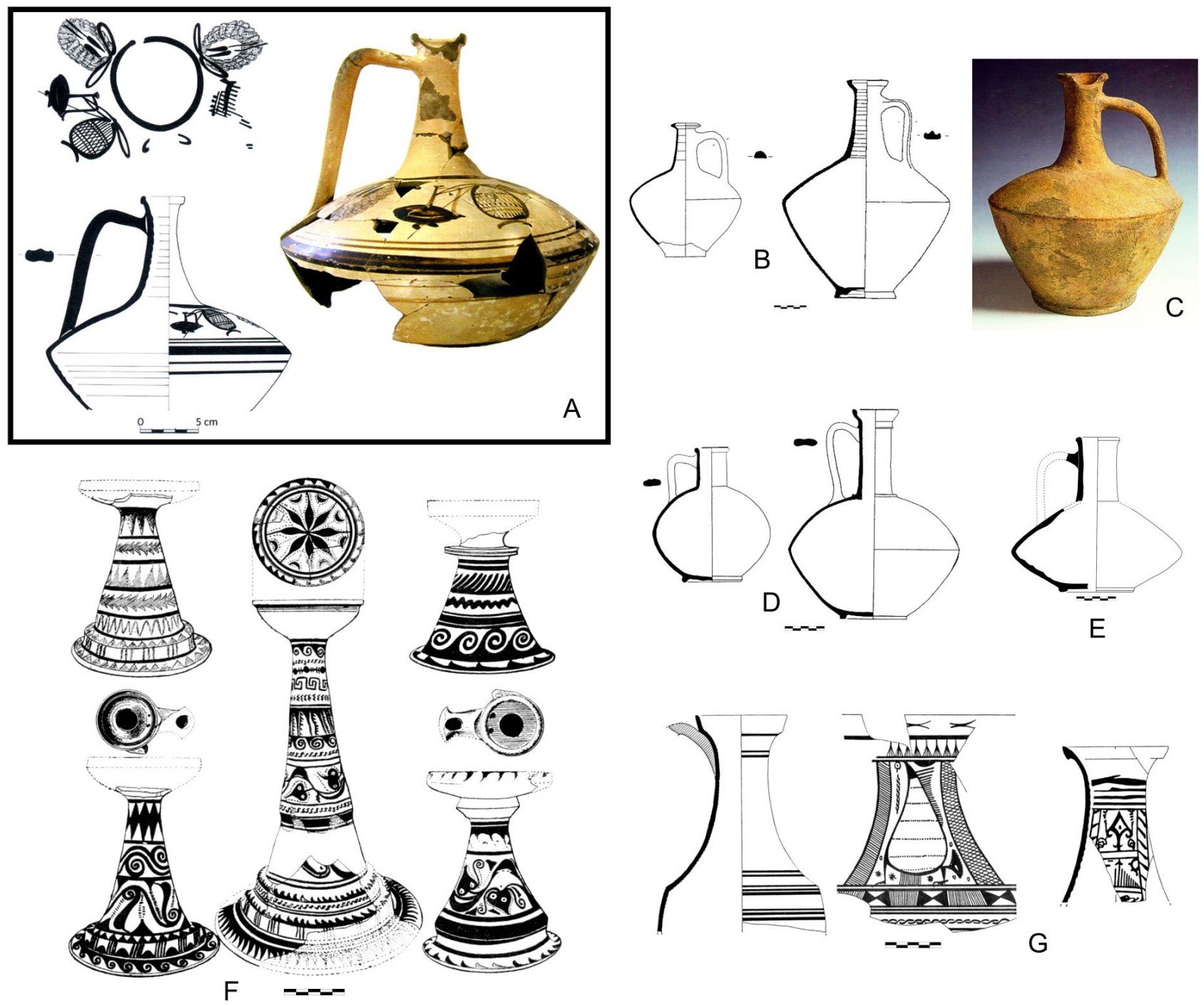

Figura 4: A. Lágynos helenístico de Libisosa (Uroz, 2012: fig. 213). B. Jarros tardorrepublicanos de Tarraco (Díaz, 2000: figs. 26, nº 1 y 39, $\mathrm{n}^{\circ}$ 2). C. Botella de cerámica común del pecio Escombreras 1 (VV.AA., 2004: 169, $\mathrm{n}^{\circ}$ 45). D. Botellas catalanas augusteas (Casas et al., 1995: fig. 14, $\mathrm{n}^{\circ} 1$ y 11). E. Ejemplar de Ampurias (Aquilué et al., 2010 fig. 19, nº 8). F. Portalucernas cerámicos de Azaila (Cabré, 1944: fig. 87A). G. Olpes de tradición indígena de Zaragoza y Clunia (Abascal, 1986: figs. 50, nº 233 y 51, nº 235).

horizontales paralelas. Bajo ésta se desarrolla una secuencia de tres prótomos de aves hacia la derecha, con largos cuellos curvos, ojos circulares con punto central y alas extendidas en diagonal con el plumaje indicado mediante pequeños flecos. Entre estos seres se distinguen varios tallos doblados hacia la izquierda, de los que brotan una especie de flores con largos pétalos, elemento que también aparece bajo una línea horizontal que sirve de pauta, en grupos de dos y en direcciones opuestas. Seguidamente se indican dos líneas horizontales paralelas con grupos de siete pequeños trazos verticales en su interior, a modo de triglifos y metopas.

El friso inferior es más ancho y en él se representa una escena con tres cuadrúpedos de cuello largo, ojos circulares con punto central, hocico también largo y curvo, cuerpo delgado con rallado interno y patas estilizadas, las delanteras extendidas hacia la derecha. Uno de ellos luce unas largas orejas que, debido a la trayectoria de la marcha, quedan desplazadas hacia atrás, mientras que en los dos casos restantes estos seres presentan cornamentas esquemáticas, por lo que debe tratarse de ciervos, que huyen de un lobo que les acecha, de ahí que el primero de los herbívoros gire la cabeza hacia atrás. Dicho depredador se representa rampante, con las extremidades posteriores sobre el suelo, un gran ojo en forma de gota con punto central, fauces abiertas con los dientes indicados y fina lengua que surge de su interior, cuello y torso ocupado por partes ralladas y otras en retícula, mientras que los cuartos traseros están simplemente rellenos por tinta plana. Bajo el cuerpo del primer cérvido aparece un brote en espiral, también presente bajo las patas delanteras del individuo hembra, mientras que pequeños roleos se intuyen tras el lobo y entre el segundo y tercer ciervo. El espacio bajo el cuerpo del atacante, al igual que ocurre en el caso del segundo y tercer cérvido, lo ocupan peces de cuerpos arqueados, escamas indicadas y grandes ojos circulares con punto central. 


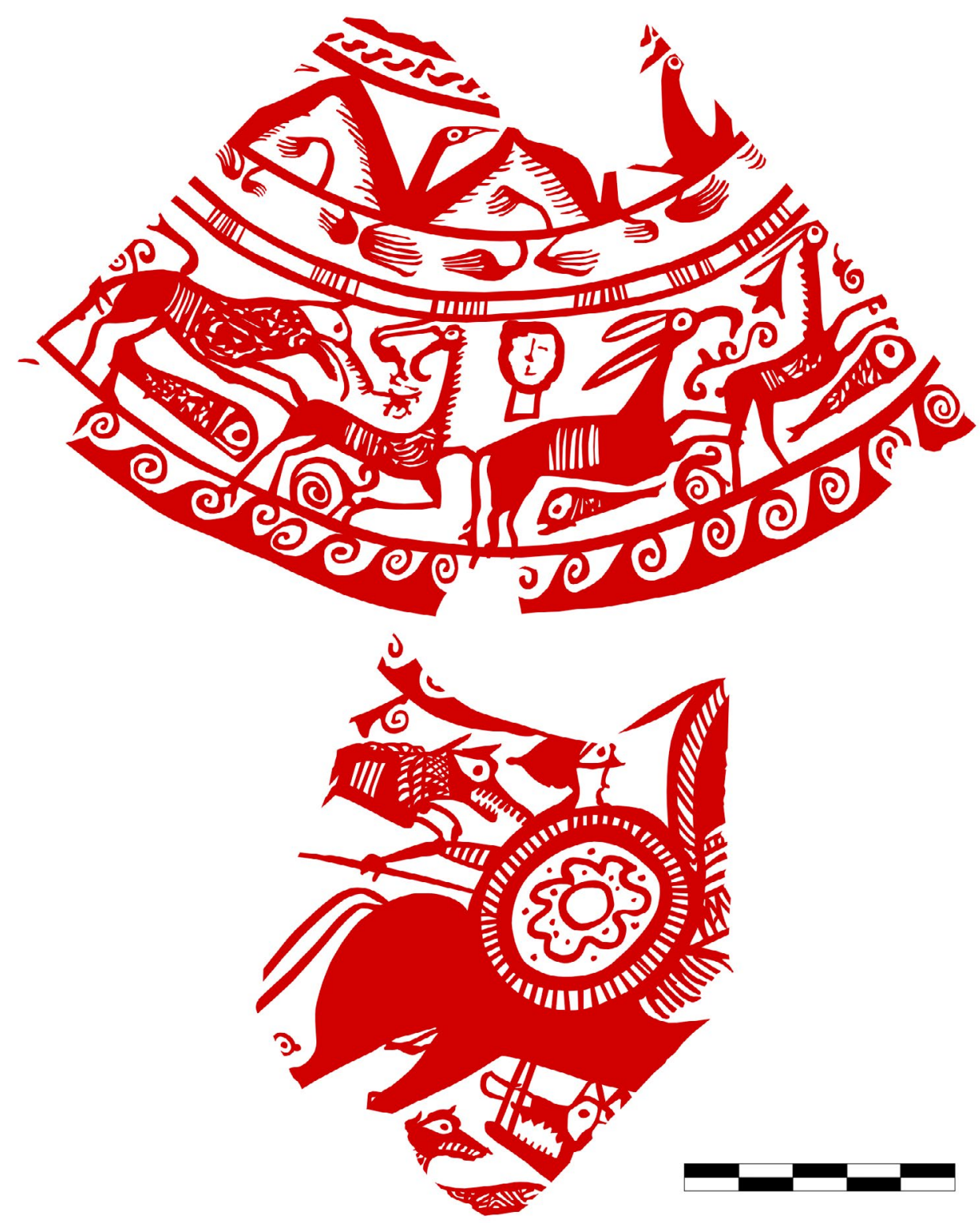

Figura 5: Desarrollo de la decoración pintada del lágynos de Lucentum.

Entre el primer y segundo cérvido aparece una cabeza humana, hoy prácticamente desaparecida, en la que se distingue un largo cuello, rostro frontal ovalado y cabello corto, quizás partido en dos sobre la frente.

Toda esta escena reposa sobre otra cenefa horizontal, compuesta por una sucesión de postas enlazadas hacia la derecha, precediendo el arranque del cuerpo y la escena principal. En ella ocupa la posición central un jinete cabalgando hacia la derecha, con cabeza pequeña en la que se representa un gran ojo en forma de gota con punto central, así como una nariz y barbilla puntiagudas. El personaje va pertrechado con casco en forma de capacete picudo sin carrilleras «tipo Montefortino», deslizado hacia atrás, y un faldellín corto cuyos flecos asoman por debajo de un gran escudo que oculta buena parte de su cuerpo. Éste, de forma circular tipo caetra, dispone en el umbo de una especie de roseta central con puntos en sus pétalos y fuera de ellos, y un grueso ribete rallado que sirve de contorno. A la izquierda de la rodela asoma uno de los brazos del jinete sujetando una fina lanza en ristre. Del caballo que monta sólo se conserva parte del cuello, con las crines indicadas por cortos trazos paralelos. En la base del cuello se aprecian algunas zonas con rallados o zigzag, mientras que el resto del cuerpo se recurre a la tinta plana, empleándose dos líneas paralelas para la cola. Tras el jinete se observa buena parte del cuerpo de un lobo, con cuello reticulado y costillas marcadas por un sector rallado, pequeños arcos superpuestos señalando el pelaje del lomo, gran ojo con punto central, orejas puntiagudas, boca entreabierta con indicación de los dientes y pequeñas patas adelantadas hacia el guerrero. Sobre este animal asoma un elemento vegetal indeterminado y por debajo del caballo otros tres animales. Tras sus patas se distingue un ojo circular con punto central y una especie de pico muy corto, 
puede que perteneciente a un ave o a una liebre. Bajo el cuerpo del équido aparece la cabeza de un posible perro, vuelta hacia la derecha, con ojo en forma de gota y punto interno, pequeñas orejas puntiagudas, boca cerrada aunque advirtiéndose la dentadura y cuerpo rallado. Junto a éste y girada hacia la izquierda, una cabeza de mayor tamaño con gran ojo, orejas triangulares y fauces abiertas y dos grandes colmillos paralelos que parten del extremo de la mandíbula, por lo que debe tratarse de un jabalí.

\section{LA CERÁMICA IBÉRICA DE «ESTILO SIM- BÓLICO»Y EL TOSSAL DE MANISES}

La cerámica ibérica decorada con figuraciones animales y antropomorfas se encuentra sobradamente atestiguada en este yacimiento, registrándose un considerable volumen de piezas clasificables dentro del «estilo simbólico» o «Elx-Archena» ${ }^{8}$. El propio Enrique Llobregat subraya la importancia de estas producciones características de la Contestania, cuya cronología sitúa en el tránsito entre los siglos II y I a. C. (Llobregat, 1972: 70-71 y 188), si bien este investigador clasificó el lágynos lucentino dentro del «estilo narrativo» u «Oliva-Llíria» (Llobregat, 1972: 185), lo cual se contradice con el tipo de representación de jinetes con escudos circulares, túnicas cortas y cascos «tipo Montefortino», que encaja más bien con los repertorios del ámbito ilicitano 9 (Santos, 2004: fig. 135).

Bajo la denominación de «Elx-Archena» se ha querido agrupar a un conjunto de decoraciones sobre cerámica que, partiendo de un mismo sistema iconográfico, cuenta con numerosas variantes locales y regionales (Abad y Sanz, 1995: 73; Grau, 2005: 116117) y en todo caso no sirve para definir una manera de representación única (Aranegui, 2000: 293-295; Tortosa, 2006: 149) ni se corresponde con una realidad arqueológica, encontrándose desde los años 90 en redefinición ${ }^{10}$. Considerando que el principal foco de producción y difusión de estas cerámicas se localiza

8. Conviene recordar casos como el del fragmento CS 3007, en el que un individuo con rama marcha a caballo hacia la izquierda, con la cabeza de un gran lobo frente a él (Lafuente, 1932: foto $23, n^{\circ} 16$; 1934: lám. XVII, $n^{\circ}$ I; 1944: figs. 29 y 31; 1959: lám. XVII; Llobregat, 1972: fig. 106; Olmos, 1988-89: 99, fig. 10; Maestro, 1989: 287-288, fig. 105a), animal que aparece también en los fragmentos CS 3009 y 3015 (Lafuente, 1934: 44, lám. XVII, nº II; Verdú y Olcina, 2012: 162-163, fig. 7).

9. En estos talleres, en cambio, no son características las escenas de caza (Pérez Blasco, 2014: 143), de ahí probablemente la opinión de Llobregat.

10. Para el origen y el debate sobre este concepto, hoy en desuso, destacan, además de trabajos de síntesis como el de García Hernández (1987), las recientes reflexiones de Santos (2010: 146-147) y Pérez Blasco (2014: 33 ss. y 367-370), y sobre todo de Tortosa (1998: 207-210; 2004a: 71 ss.; 2006: 79 ss.), investigadora que presenta una nueva propuesta en l'Alcúdia d'Elx, el momento de máxima actividad de sus alfares se establece hoy entre el siglo II a. C. y mediados del siguiente.

En estas cerámicas se plasma una naturaleza en movimiento, con una vegetación exuberante entre la cual se desenvuelven animales y humanos (Olmos, 1988-89: 88-90) integrados con frecuencia en escenas individuales en las que muestran su poder luchando contra monstruos fabulosos. La mayor parte de los motivos antropomorfos se localizan en amplios frisos, siendo el horror vacui otro rasgo esencial de este tipo de decoraciones (García Hernández, 1987: 15-16 y 26; Tortosa, 1998: 208-209), las cuales se registran, como sucede en el Tossal de Manises, tanto en grandes recipientes (tinajas, lebétes, grandes kálathoi), como en contenedores de tamaño medio para la despensa o vajilla de mesa (caso de los oinokhóai), excepcionalmente en vasos pequeños y de carácter ritual (phialái, caliciformes, copas, kérnoi). Se percibe que el artesano que decora estos objetos opera en el seno de una sociedad que demanda este tipo de productos, expresando estas figuraciones su cultura y creencias religiosas y confiriendo a sus respectivos soportes un elevado valor al reconocerse en ellos las altas jerarquías. Tal sería el caso del lágynos de Lucentum, un vaso fabricado probablemente por encargo, un singular bien de prestigio, el cual le vendría otorgado sobre todo por su rica decoración, propiedad de algún notable de la ciudad.

\section{EL LÁGYNOS DEL JINETE DE LUCENTUM. ANÁLISIS ICONOGRÁFICO}

\subsection{El EMBLEMA HABITUAL: LA IMAGEN DEL JINETE}

El jinete es el protagonista indiscutible de la escena central, aunque solamente se conserva parcialmente y con el cuerpo oculto tras una gran rodela. Por encima de ésta asoma una pequeña cabeza en la que se representa un gran ojo al «modo ilicitano», como es posible apreciar, entre otros muchos ejemplos, en el varón del «Vaso del Héroe» (Pericot, 1979: fig. 126; Ramos Fernández, 1982: 118, ss., láms. 4 y 5, nº 2; Maestro, 1989: 224-226, fig. 74). Sin embargo, el elemento más interesante es el casco, que es posible clasificar como del «tipo Montefortino»» ${ }^{11}$.

Este tipo de casco es prácticamente el único documentado para la segunda Edad del Hierro, apareciendo en cantidades significativas en la Península Ibérica ${ }^{12}$

metodológica, clasificando los diferentes tipos de decoración en «estilos» a partir de la temática y morfología de sus componentes.

11. En ocasiones también denominado «gorra de jockey», debe el nombre a su descubrimiento en la necrópolis celta de Montefortino (Ancona, norte de Italia).

12. Existe una nutrida bibliografía sobre este elemento, destacando varios investigadores que han atendido a los hallazgos peninsulares como J. M. Blázquez (1959-60), que los 
(Kurtz, 1992: 207-208; Quesada, 1989: 18; 1992: 65; 1997: 551 ss., fig. 316). Se compone de un capacete hemisférico rematado por un apéndice terminal perforado para sujetar un penacho de crines o plumas, un guardanucas corto e inclinado y correas para barboquejo que arrancan de anillas situadas en el centro del guardanucas para unirse bajo la barbilla. A menudo llevaban carrilleras laterales, sujetas por bisagras y remaches (Fig. 6A) y ciertos ejemplares cuentan con decoración incisa o grabada (Abásolo y Pérez, 1980: 95-98 y 106, figs. 3 y 4, láms. I-III; Mazzoli, 2016: 130 , lám. $8, \mathrm{n}^{\mathrm{o}} 1$ ). Sus dimensiones son bastante homogéneas, con diámetros comprendidos entre los 22 y los $26 \mathrm{~cm}$ y una altura de 16 a $23 \mathrm{~cm}$ (García-Mauriño, 1993: 97, fig. 1).

El origen de estos cascos estaría en el norte de Italia y se remonta al siglo $\mathrm{V}$ a. $\mathrm{C}$., aunque en el área ibérica se fechan a partir de mediados del III a. C., perteneciendo la mayoría de ejemplares a los siglos II y I a. C. (Russell, 1975: 13-14 y 17-25, figs. 2-6 y 21-30, láms. 2-36; Quesada, 1997: 556-564; 2008: $255)$. Fueron empleados tanto por romanos como por galos, cartagineses e iberos. Se aprecia una significativa concentración de hallazgos en torno a la $2^{\mathrm{a}}$ Guerra Púnica (Abásolo y Pérez, 1980: 110; Quesada, 1997: $615)$, sobre todo en contextos funerarios, donde se insertan en ajuares relativamente ricos, aunque no deberían considerarse necesariamente como elementos suntuarios o de prestigio (García-Mauriño, 1993: 136 y 139). También destaca la alta densidad de ítems en las actuales provincias de Alicante y Murcia, con algunas penetraciones hacia el interior (Albacete, Andalucía oriental) (Quesada, 1992: 68-73, fig. 7; 1997: fig. 318B; 2008: 256 y 258; Mazzoli, 2016: 118 ss., figs. 8 y 9), y su presencia en la isla de Mallorca indicaría quizás una relación con las rutas comerciales imperantes así como con la cuestión del mercenariado, que pudo ser determinante en la transmisión del modelo ${ }^{13}$.

consideraba de raigambre céltica, o P. F. Stary (1982), que incrementa el inventario de cascos publicado poco antes por J. A. Abásolo y E. Pérez (1980). Conviene citar también la sistematización de M. Lenerz-De Wilde (1991: 179-181, fig. 136), así como las referencias de Quesada (1992: 6566; 1997: 554 ss.), que se decanta hacia un origen itálico. Aportaciones más recientes son las de J. García-Mauriño (1993), G. García Jiménez (2012: 306-313) y M. Mazzoli (2016), que distingue entre los cascos de hierro (fechados en la Península Ibérica entre la segunda mitad del siglo IV a. C. e inicios del siguiente) y los de bronce con ápice y guardanuca, de producción etrusco-itálica (siglo III al primer cuarto del I a. C.).

13. Mercenarios baleares lucharon en las filas cartaginesas, al igual que guerreros peninsulares, en especial turdetanos y celtíberos, pasando a servir a Roma tiempo después. Debido precisamente a su empleo durante la conquista romana de Iberia de la mano de estos mercenarios o de las propias legiones, algunos de estos cascos pudieron acabar en tumbas ibéricas como botín o fruto del comercio (Quesada, 1997: 564; 2010: 173-174)
Estos cascos gozaron de una amplia difusión por todo el Mediterráneo, incluida la Península Ibérica (Quesada, 2002-2003: 72-73, nota 8; García Jiménez, 2012: 321), a causa sobre todo de su adopción por el ejército romano. No se descarta que artesanos locales, partiendo de ideas y/o modelos itálicos, y aprovechando que era un elemento sencillo de fabricar, pudieran imitarlos (García-Mauriño, 1993: 132, 134 y 142, fig. 42; Quesada, 2010: 156-157). La llegada del «tipo Montefortino» a Iberia tuvo como consecuencia la aparición de una panoplia indígena fuertemente influenciada por el enfrentamiento entre romanos y cartagineses. Por otra parte, la combinación entre este casco y el escudo circular es más bien extraña para el Levante septentrional y Cataluña, siendo más habitual el escudo oval. En otras regiones, sin embargo, como sucede en las tierras valencianas, el sureste y la Alta Andalucía, se constatan todas las posibilidades (Quesada, 1997: 615 y 621, fig. 341), como corrobora en el registro arqueológico.

Entre los hallazgos más representativos se encuentra el casco de la tumba $\mathrm{G}$ de Castellones de Céal (Hinojares, Jaén), fechada en el siglo III a. C., como suele ocurrir, completamente aplastado (Fernández Chicarro, 1954: 94 y 97, fig. 39, n 2; García-Mauriño, 1993: 104-105, fig. 10; Chapa et al., 1998: 26, fig. 7, no 5; Mazzoli, 2016: 123 y 127, láms. 3, nº 4, y $8, n^{\circ} 3-4$ ) (Fig. 6B), así como el de la sepultura 11 (Mazzoli, 2016: 112 y 117, fig. 4). De la necrópolis de Tútugi (Galera, Granada) proceden varios ejemplares (Cabré y De Motos, 1918: 31, 49 y 54; Abásolo y Pérez, 1980: 108-109; Maluquer, 1987; García-Mauriño, 1993: 106-107 y 120, figs. 13-15; García Jiménez, 2012: 310-312, figs. 176-177 y 305; Mazzoli, 2016: $113,117,120,123,126-128$ y 131 , fig. 5 , láms. $1, n^{\circ} 3$, $\left.3, \mathrm{n}^{\mathrm{o}} 2,5, \mathrm{n}^{\mathrm{o}} 3, \mathrm{y} 9, \mathrm{n}^{\mathrm{o}} 2-3\right)$, que deberían datarse antes del 250 a. C. (Quesada, 1997: 560). Otros cascos del «tipo Montefortino» se conocen en la necrópolis de Villaricos (Almería), propiedad quizás de mercenarios o soldados auxiliares bajo el estandarte de Cartago, de fines del III a. C. (Siret, 1906: 454-455, lám. VI, nº 42; Astruc, 1951: 77-78, lám. XLVIII, no 1-3; Abásolo y Pérez, 1980: 104-105; García-Mauriño, 1993: 120123, figs. 34; Mazzoli, 2016: 127 y 131, láms. 4, nº 1 , y $\left.9, n^{\circ} 4-7\right)$, cronología similar a los recuperados en las tumbas 146 y 428 de Cabecico del Tesoro (Verdolay, Murcia) (Nieto, 1939-40: 152-154, fig. 12, lám. XXIX; 1944: 10, lám. XXVI; Abásolo y Pérez, 1980: 103 y 109; Quesada, 1986-87: 60; 1989: 17-19, 155 y 199, láms. IV y XVII-XIX; 1990: 234-235, figs. 1, $\mathrm{n}^{\mathrm{o}}$ 7, 5, 6 y 9; García-Mauriño, 1993: 103, fig. 7; Mazzoli, 2016: 123 y 126-128, láms. 3, no 1, y 6, n ${ }^{\circ} 1$ ) (Fig. 6C). El ejemplar de hierro de la sepultura 478 de El Cigarralejo (Mula, Murcia) (Fig. 6D) se ha considerado, con reservas, del segundo cuarto del siglo IV a. C., por lo que sería el más antiguo de Iberia (Quesada, 1997: 559-560; García Jiménez, 2012: 306-308, figs. 171-172 y 303; Mazzoli, 2016: 111 y 117, fig. 2). Resulta igualmente discutible la cronología del 

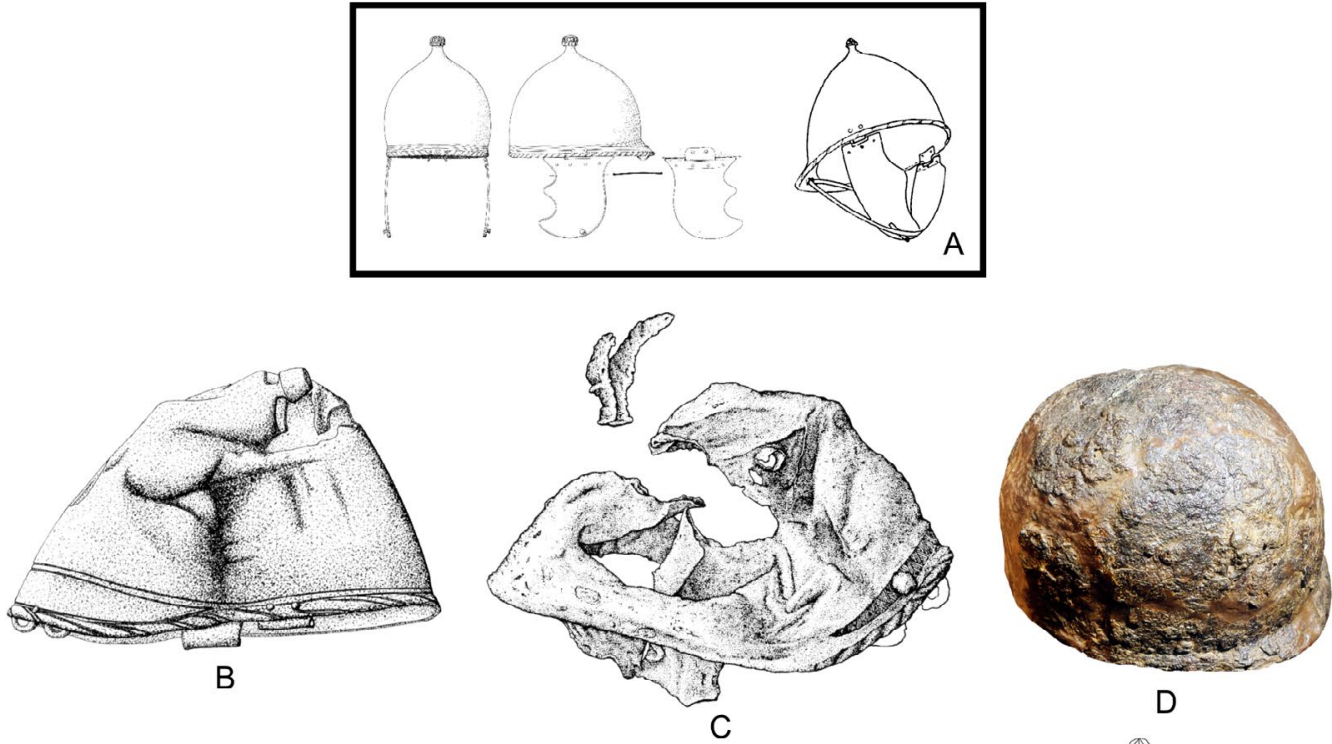

D

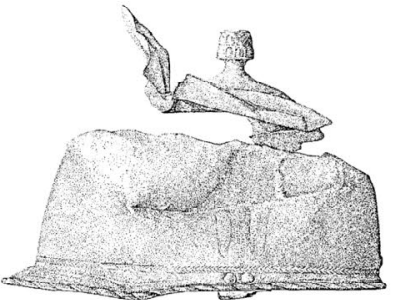

$\mathrm{E}$

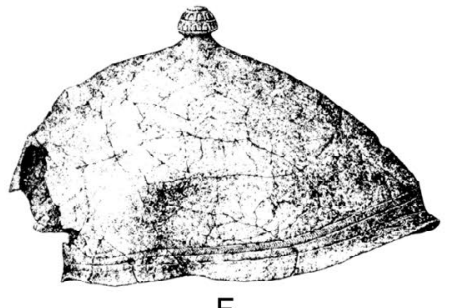

$\mathrm{F}$

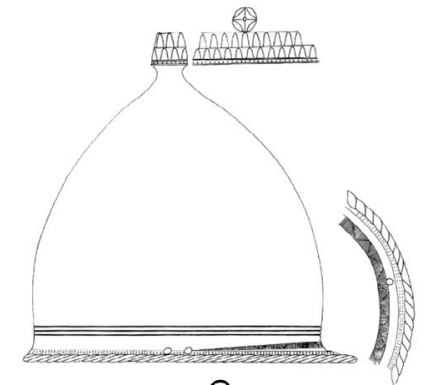

G
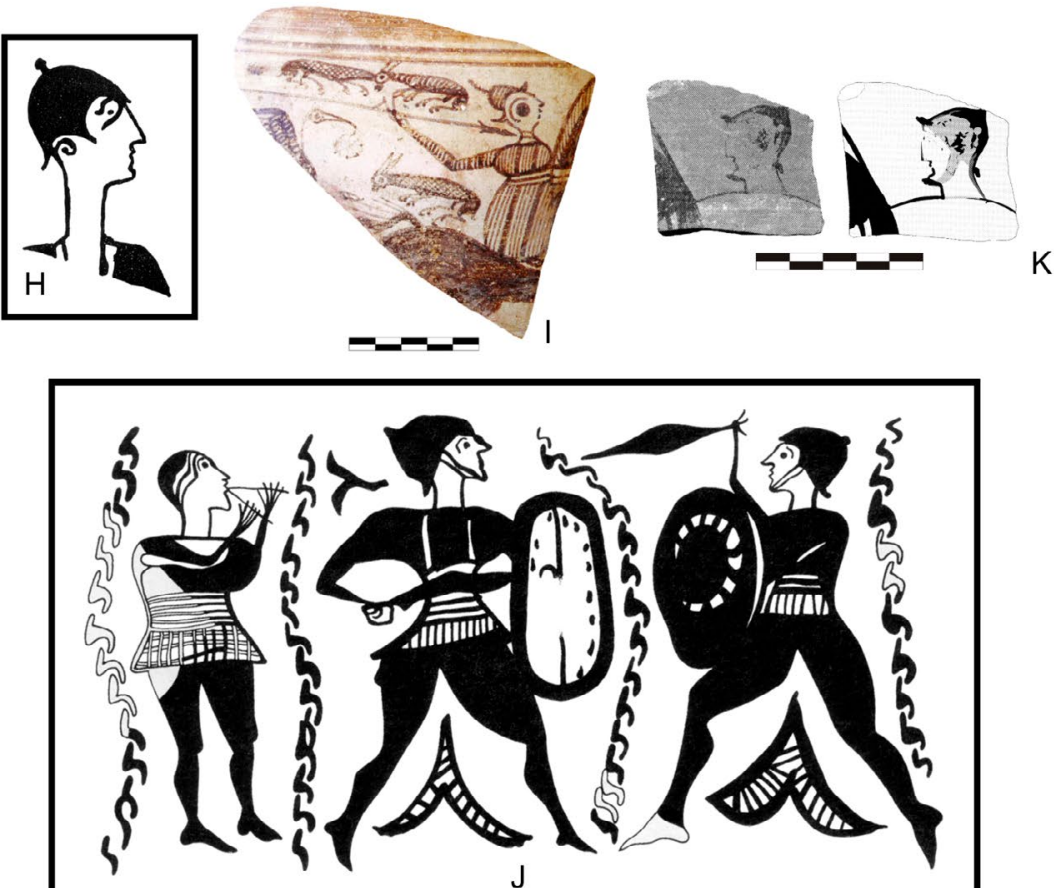

Figura 6: A. Reconstrucción ideal de un casco «tipo Montefortino» (a partir de Russell, 1975: figs. 2 y 6, y Abasolo y Pérez, 1980: fig. 5). B. Ejemplar de la tumba G de la necrópolis de Castellones de Céal (Chapa et al., 1998: fig. 7, $\mathrm{n}^{\circ}$ 5). C. Casco de la sepultura 428 de Cabecico del Tesoro (Quesada, 1989: 199). D. Ejemplar de hierro de El Cigarralejo (foto Museo Monográfico de Arte Ibérico «El Cigarralejo»). E. Casco de la tumba 4F2 de Pozo Moro (Alcalá-Zamora, 2003: fig. 29b). F. Casco de Hoya de Santa Ana (García-Mauriño, 1993: fig. 16). G. Reconstrucción de un yelmo del Museo de la Ciudad de Benicarló (Oliver, 1987-88: fig. 2). H. Individuo con casco «tipo Montefortino» de Sant Miquel de Llíria (Maestro, 1989: fig. 62c). I. Fragmento cerámico de l'Alcúdia (Tendero y Ronda, 2014 : fig. 8). J. Escena con monomaquia y auletér sobre un vaso procedente de Libisosa (Uroz, 2012: fig. 290). K. Fragmento hallado en El Palao (Moret et al., 2012: fig. 13). 
casco de la sepultura 4F/2 de Pozo Moro (Chinchilla de Montearagón, Albacete) (García-Mauriño, 1993: 115, fig. 27; Quesada, 1997: 562, fig. 318, lám. XIB; 2002-2003: 77, nota 7; Alcalá-Zamora, 2003: 56-57 y 130-131, figs. 4.57 y 29b; Mazzoli, 2016: 122-123 y 126, lám. 2, no 4-5) (Fig. 6E). En la también albacetense necrópolis de Hoya de Santa Ana se recuperaron varios ejemplares, uno de ellos (Fig. 6F) inserto en un ajuar compuesto por una panoplia de guerrero completa (Sánchez, 1943: 11 y 21, láms. IX-XI; Abásolo y Pérez, 1980: 103; García-Mauriño, 1993: 108, fig. 16; Mazzoli, 2016: 123, 127 y 130, lám. 3, nº 6) y con un kálathos del tipo «sombrero de copa» de fines del siglo III y II a. C. como urna cineraria. Otro casco de hierro se localizó en Libisosa (Uroz, 2012: 300, 343 y 345, figs. 234i y 263; Uroz y Uroz, 2014: 211, fig. 10e; Mazzoli, 2016: 111 y 117, fig. 3). De fines del III a. C. serían también los restos de casco de bronce del Tossal de les Basses (Alicante) (Rosser y Fuentes, 2007: 4849 y 93; Mazzoli, 2016: 120 y 126, lám. 1, no 2) y el fragmento de «botón» de la sepultura 18 de la Serreta (Alcoi, Alicante) (Mazzoli, 2016: 125 y 128, lám. 6, no 5-7). Destacamos también la reciente identificación de una paragnatide o protección de mejilla en la Penya de l'Àguila (Dénia, Alicante), esta vez procedente de un contexto sertoriano (Sala et al., 2013: 197, fig. 4, $\mathrm{n}^{\circ}$ 3; Bayo, 2014: 112, fig. 5, no 2; Mazzoli, 2016: 121 y 126, lám. 1, no 5). Entre los hallazgos más septentrionales conviene citar el de los tres ítems del fondeadero de Piedras de las Barbadas (Benicarló, Castellón), un posible depósito ritual efectuado por los romanos tras una victoria naval a fines de la $2^{\mathrm{a}}$ Guerra Púnica (Fernández Izquierdo, 1980: 149, fig. 3, no 2; lám. Ic; Oliver, 1987-88: 206 ss., figs. 1-2, lám. I; García-Mauriño, 1993: 101 y 139, fig. 5; Mazzoli, 2016: 121-122, 124 y 126, láms. 2, no 1-2, y 5, no 2) (Fig. 6G). Otros ejemplares broncíneos, muy fragmentados y plenamente romanos, se identifican en la necrópolis emporitana de les Corts (l'Escala, Girona) (Almagro Basch, 1953: 261, 279, 299 y 354, figs. 227, no 5, 253, no 1 y 336, nº 1; Abásolo y Pérez, 1980: 100-101; GarcíaMauriño, 1993: 110-111, figs. 20-22; Quesada, 1997: 559; Mazzoli, 2016: 129, lám. 7, no 7-9).

Pese a todo, estos cascos metálicos se encuentran poco documentados, debido quizás a que no serían habitualmente amortizados, y su presencia entre las comunidades ibéricas queda atestiguada de manera indirecta a través de las decoraciones cerámicas (Quesada, 1997: 567, fig. 323; Aranegui, 2012: 123), siempre en piezas excepcionales identificadas tanto en la Contestania como en el territorio de Edeta, la Oretania y el Bajo Aragón. Probablemente quienes decoraron estos vasos habrían visto cascos reales, de ahí la fidelidad de las representaciones, como se aprecia en un fragmento hallado en el Tossal de Sant Miquel (Ballester et al., 1954: 76, lám. LXXII, no 8; Pericot, 1979: fig. 277a; Maestro, 1989: 183-184, fig. 62c; Bonet, 1995: 153, fig. 72, n 29) (Fig. 6H). También se registran en la cerámica ilicitana (Ramos Folqués, 1961; 1990: lám 63;
Maestro, 1989: 246-248, fig. 87a; Tendero y Ronda, 2014: 225, fig. 8) (Fig. 6I). En la «Tinaja de los Caballeros» de Libisosa (Uroz, 2012: 313-314 y 341, figs. 243-244 y 261; 2013: 54 ss., fig. 2) los jinetes portan, como sucede en el lágynos del Tossal de Manises, amplios escudos circulares, uno de ellos con una roseta central. Destaca también una imitación de crátera en la que se enfrentan dos infantes ataviados con cascos «tipo Montefortino» en los que se aprecian incluso las correas de sujeción (Uroz, 2012: 321 y 343, figs. 247, 262 y 290; 2013: 62 ss., fig. 9; Pérez Blasco, 2014: 870-871, fig. 207, $\mathrm{n}^{\circ}$ 1-2) (Fig. 6J). Se determina una cronología para estas piezas de fines del II e inicios del I a. C., al igual que ocurre con el fragmento recuperado en El Palao (Alcañiz, Teruel) (Moret et al., 2012: 208-209, fig. 13; Maestro, 2013-14: 86, nota 79, fig. 11b) (Fig. 6K), donde un individuo luce otro de estos cascos y se intuye el contorno de lo que podría ser una gran rodela.

En relación a este último elemento, la aparición de una serie de motivos en su interior hace pensar en la representación de una caetra ${ }^{14}$ con una profusa decoración y los remaches de sujeción de la cobertura de cuero o metal indicados por puntos en disposición radial. El umbo se indica con un círculo central y la línea ondulada que lo rodea evoca piezas como las documentadas en Cabezo Lucero (Guardamar del Segura) (Aranegui et al., 1993: 125 y 242, fig. 79, $\mathrm{n}^{\mathbf{0}} 1$; Quesada, 1997: 510, fig. 295, lám. XC) o la Serreta ${ }^{15}$ (Cortell et al., 1992: 103, fig. 14; Quesada, 1997: 511, fig. 295; Reig, 2000: 100-105, láms. IX-XI) (Fig. 7A y B). Esta roseta pudo inspirarse en el modelo de umbo con prolongaciones radiales redondeadas (tipo Quesada IIA), registrado básicamente en la Meseta Oriental, aunque también se constatan algunos restos descontextualizados en yacimientos del sureste como Casa del Monte, Hoya de Santa Ana o Llano de la Consolación (Quesada, 1997: 511-512, fig. 296). Mención especial merece el ejemplar de la necrópolis púnica de Villaricos (Siret, 1906: 83, lám. XV, nº 48) (Fig. 7C).

La caetra ibérica sería un escudo muy útil en el combate cuerpo a cuerpo, apto tanto para infantes como para jinetes ligeros (Quesada, 1997: 531), cuya estrategia se basaba en la rapidez de movimientos (Kurtz, 1992: 209), aunque debió ser un estorbo para la caza (Mata et al., 2013: 184-185). Con unas dimensiones comprendidas entre los 50 y $70 \mathrm{~cm}$ de diámetro (Quesada, 2010: 135-138), podrían ser de hasta $1 \mathrm{~m}$ en casos excepcionales. A partir sobre todo de la $2^{\mathrm{a}}$ Guerra Púnica se impone en Iberia el scutum oval (González Jiménez, 2012: 250), pero antes de este conflicto,

14. Sobre el escudo circular ibérico véase Quesada, 1989: 8 ss.; 1997: 489 ss., etc.

15. Mientras que en el primer caso la pieza dispone de un diámetro de algo más de $35 \mathrm{~cm}$ y se inserta en un contexto de la primera mitad del siglo $\mathrm{V}$ a. C., el escudo alcoyano cuenta con $24,5 \mathrm{~cm}$ de diámetro y se fecha a fines del IV a. C. 

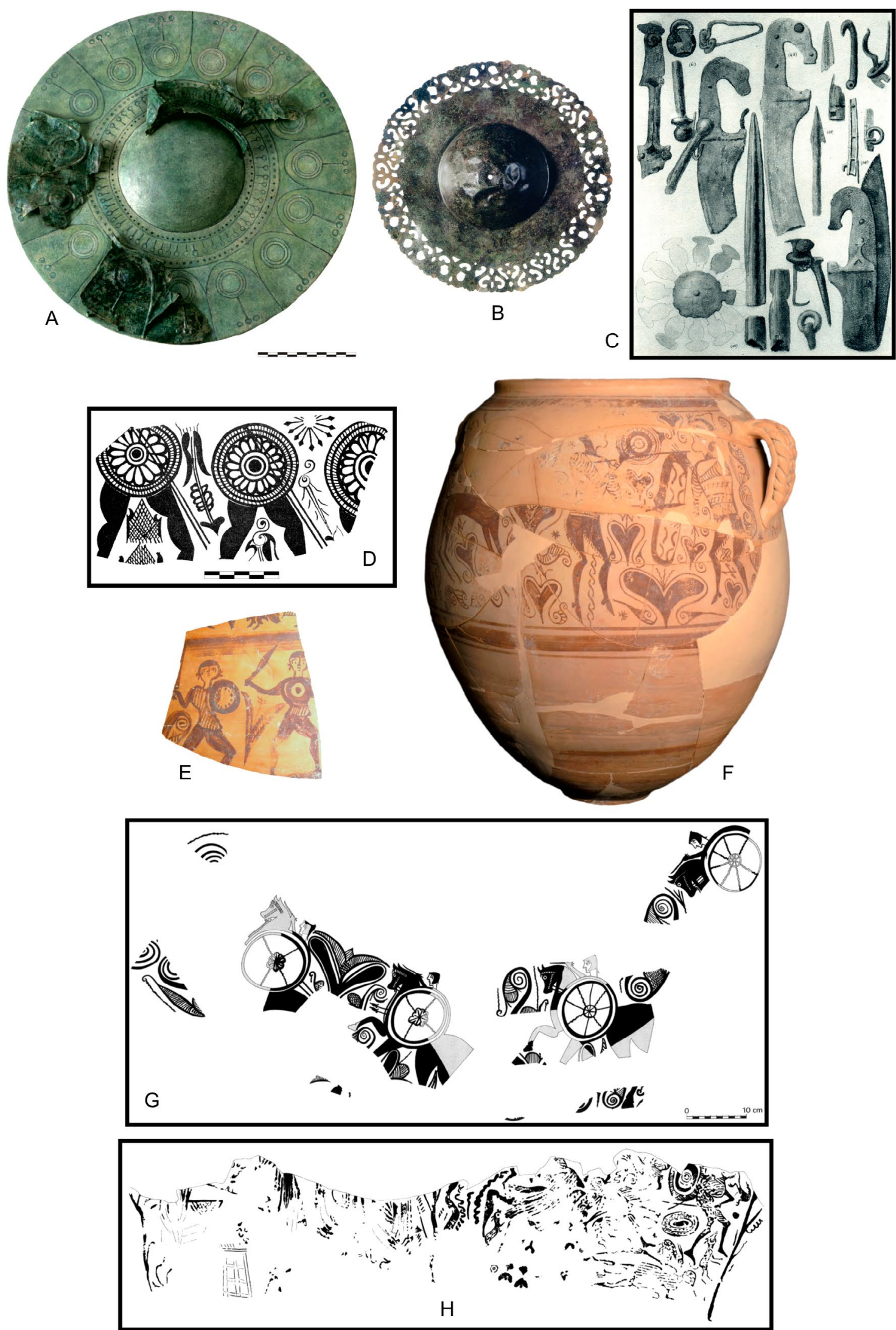

Figura 7: A. Escudo de bronce de la necrópolis de Cabezo Lucero (foto Archivo Gráfico MARQ). B. Umbo de caetra con decoración calada de la Serreta (foto Museu Arqueològic «Camil Visedo» d'Alcoi). C. Conjunto de armamento metálico procedente de Villaricos (Siret, 1906: lám. XV). D. Decoración pintada sobre un fragmento cerámico del Tossal de Cala (Maestro, 1989: fig. 101). E. Fragmento con infantes del Tolmo de Minateda (foto Museo Arqueológico Comarcal de Hellín). F. «Vaso de los Guerreros» de la Serreta (Fuentes, 2006: lám. I). G. Desarrollo de la decoración sobre una tinaja de Libisosa con escena de guerreros (Uroz, 2012: fig. 244). H. Decoración sobre cerámica de El Fapegal (Rosser y Soler, 2014: fig. 11). 


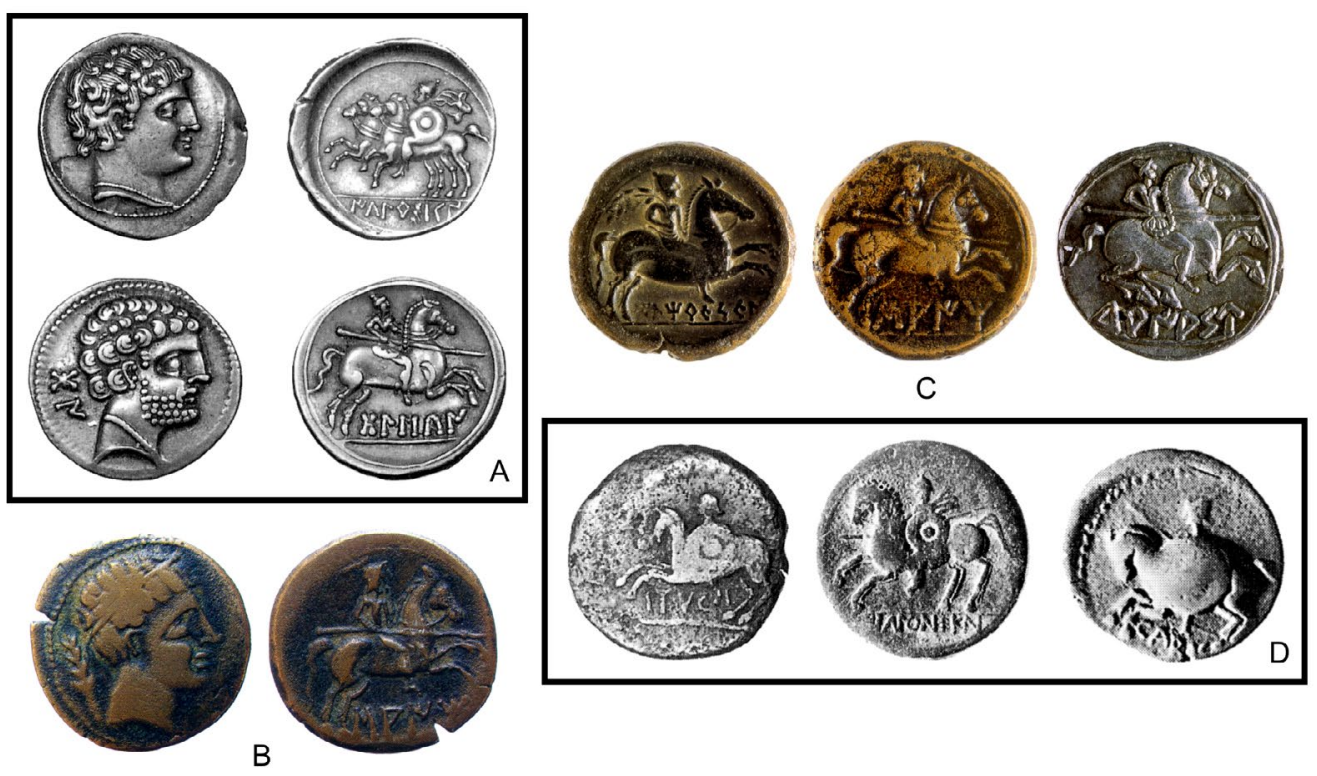

Figura 8: A. Denarios de plata de Ikalesken (175-125 a. C.) y Bolskan (82-72 a. C.) (Villaronga, 1994: ${ }^{\circ} 324,1$ y 212, 13). B. As de Saitabi (segunda mitad del siglo II a. C.) (foto Archivo Gráfico MARQ). C. Unidades de Iltirkesken y Saitabi y denario de Turiasu (Ripollès y Abascal, 2000: n 1098, 967 y 1444). D. Ases de Ituci, Ikalesken y Carissa (siglos II y I a. C.) (García-Bellido y Blázquez, 2001b: 83, 173 y 216).

el tipo más habitual entre las tropas cartaginesas era el escudo circular de gran tamaño (Quesada, 2002-2003: 75-76), lo que pudo influir en la escena plasmada en el lágynos y nos hace recordar la adscripción púnica de la primera fortificación del Tossal de Manises.

Existen numerosas representaciones de escudos circulares en el sureste peninsular, siempre de frente para apreciar su morfología o quizás para evitar el dibujo de la anatomía humana, como sucede en el fragmento con parada militar del Tossal de la Cala (Benidorm) (Belda, 1953: fig. 86; Nordström, 1973: 163 ss., fig. 47, no 2, lám. XL, nº 1; Pericot, 1979: fig. 79; García Hernández, 1986: 74, 162 y 163, lám. XL, nº 1; Maestro, 1989: 280-281, fig. 101; Tortosa, 2006: $\mathrm{n}^{\circ}$ 201, lám. 52; Bayo, 2010: 103, fig. 9, nº 4) (Fig. 7D). Otros paralelos interesantes serían las escenas representadas en un vaso de Cabecico del Tesoro hallado fuera de contexto (Nieto, 1944: 6-7, lám. XIII; Quesada, 1997: 521, lám. XIVD) o la de un fragmento del Tolmo de Minateda (Hellín, Albacete) (Quesada, 2010: 84) (Fig. 7E). En las cerámicas del Tossal de Sant Miquel estos escudos aparecen junto a otros del tipo oval (Bonet, 1995: 100 y 172, figs. 34 y 82, $n^{\circ}$ 17; Pérez y Mata, 1998: 242, fig. 4, n ${ }^{\circ} 127$ ), siendo más habituales los scuta en la Serreta, pese a que en el «Vaso de los Guerreros» un infante sujeta en alto una pequeña caetra (Fig. 7F) y otra cuelga en el lateral de un caballo (Grau, 1996: 93 y 104-105, figs. 6, 15 y 18; 2006: 64-65; Olmos y Grau, 2005: 84 ss.; figs. 3-4, lám. I; Fuentes, 2006: 50-57, figs. 2 y 25, láms. I y II; 2007: 108, 114, 120 y 134, figs. 45, 48 y 52E), con el umbo indicado por un círculo con puntos en su interior, rodeado de una secuencia de SSS. No cabe duda del carácter emblemático del escudo circular ibérico, de ahí que incluso en ocasiones se represente con un tamaño desproporcionado ${ }^{16}$, como sucede en Libisosa (Uroz, 2012: 376, fig. 280; 2013: 57-59, fig. 6) (Fig. $7 \mathrm{G})$. También destaca la representación de guerreros, uno de ellos quizás con otra caetra, en un crateriforme hallado en contexto tardorrepublicano en la necrópolis de El Fapegal (Alicante) (Rosser y Soler, 2014: 85-86, 90-91 y 95-97, figs. 9, 11, 19, 21 y 26-27) (Fig. 7H).

Pese a la abundancia de jinetes en el reverso de ciertas emisiones monetales ibéricas y celtibéricas, resulta complicado clasificar sus cascos debido al escaso nivel de detalle (Quesada, 1992: 70; 2002-2003: 86-87). Por otra parte, el circular es el único tipo de escudo representado en estas monedas, puede que por tratarse del modelo genuinamente indígena. Estas emisiones del «jinete ibérico», sobre todo de mediados del siglo II y primera mitad del I a. C., se corresponden con ases de bronce y denarios de plata acuñados por diversas cecas de la Hispania Citerior (Bolskan, Ikalesken, Kelin, Arse, Saiti, etc.) (Vives, 1924: 28 ss. láms. XXI-LXVII; Guadán, 1980: 62 ss.; Villaronga, 1994: 158 ss.; 1995; Almagro-Gorbea, 1995a; 1995b: 236 ss.; 2005; Domínguez, 1998: 124 ss.; Llorens, 1998: 51-55, figs. 1, no 1-6, y 2, no 9-11; Ripollès y Abascal, 2000: 155 ss.; García-Bellido y Blázquez, 2001a: 63-68, fig. 15; Arévalo, 2002-2003: 246-249, fig. 3; 2003: 63 ss.; Paz y Ortiz, 2007: 91 ss.) (Fig. 8). Estos guerreros suelen aparecer con lanzas en ristre,

16. Existe una evidente relación entre estos grandes escudos y los jinetes ataviados con cascos del «tipo Montefortino» (Pérez Blasco, 2014: 848-849), revelando así que ambos elementos debieron ser contemporáneos, si bien no servirían para identificar ni una etnia ni una determinada área geográfica. 

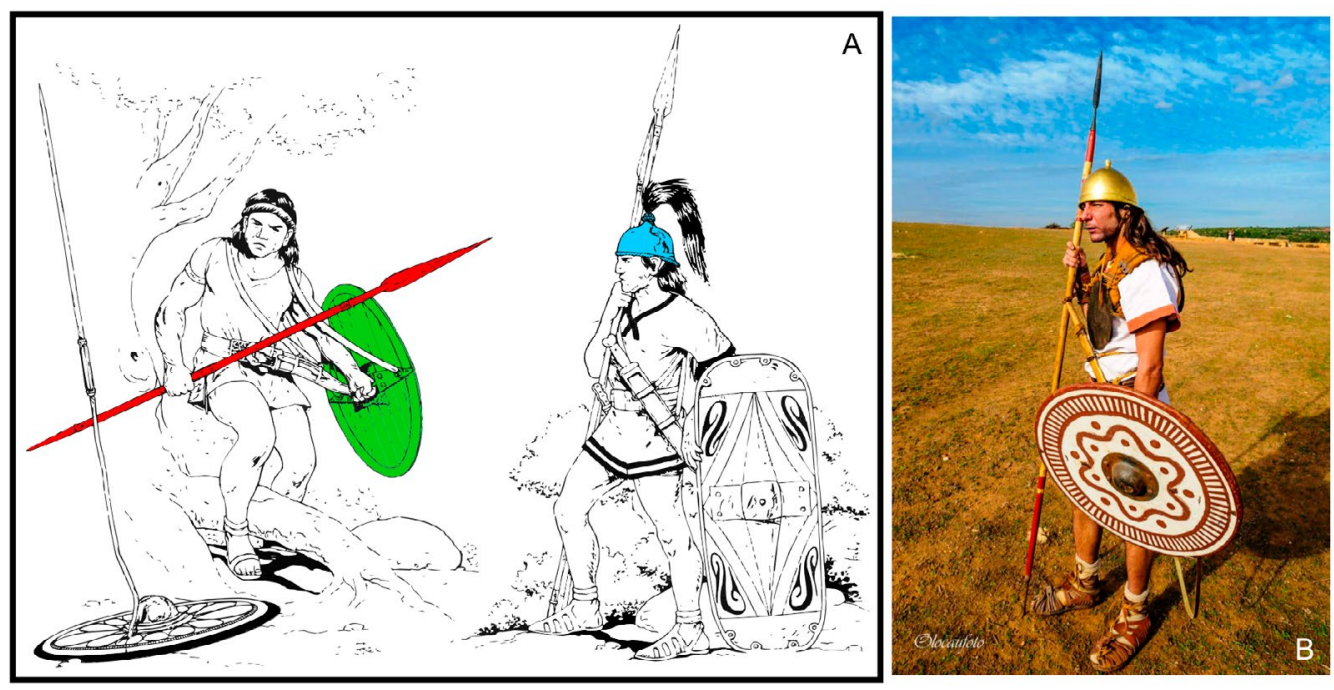

Figura 9: A. Recreación de un guerrero ibérico típico del siglo IV a. C. y de un mercenario al servicio de Cartago de fines del siglo III a. C. (a partir de los dibujos de Carlos Fernández del Castillo publicados en Quesada, 1997: figs. 339 y 340), con indicación de los elementos identificados en el lágynos del Tossal de Manises. B. Guerrero ibérico en las jornadas de recreación histórica Kelin, asentamiento ibero (16-X-2016), celebradas en Caudete de las Fuentes (Olocau, Castelló) (foto Olocaufoto).

como sucede en las cerámicas del valle del Ebro y la Celtiberia, inspiradas posiblemente en la iconografía monetal (Almagro-Gorbea y Torres, 1999: 90) como podría suceder también con el lágynos de Lucentum. En la cerámica ilicitana, sin embargo, el arma es sostenida en alto (Quesada, 1997: 414-415 y 419, fig. 252), dispuesta a ser arrojada o se encuentra firmemente sujeta a la altura del cuerpo.

Las armas se registran en las decoraciones cerámicas ibéricas en escenas tanto bélicas como venatorias y estarían dotadas de un contenido simbólico. Cabe decir en este sentido que a partir de mediados del siglo
III a. C. se incorporan novedades de raigambre helenística en la panoplia de los pueblos ibéricos del Levante, sureste y sur peninsular tales como los escudos ovales, los cascos metálicos y las espadas de hoja recta y doble filo derivadas de los viejos modelos de La Tène (Quesada, 2002-2003: 72 ss.) que, sin embargo, no llegaron a sustituir completamente al repertorio tradicional basado en el escudo circular, el casco de cuero y la falcata (Fig. 9). Un ejemplo de esta mezcolanza podría encontrarse en la escena analizada, en la que se combinan elementos tradicionales y la importante innovación que supone el casco «tipo Montefortino».
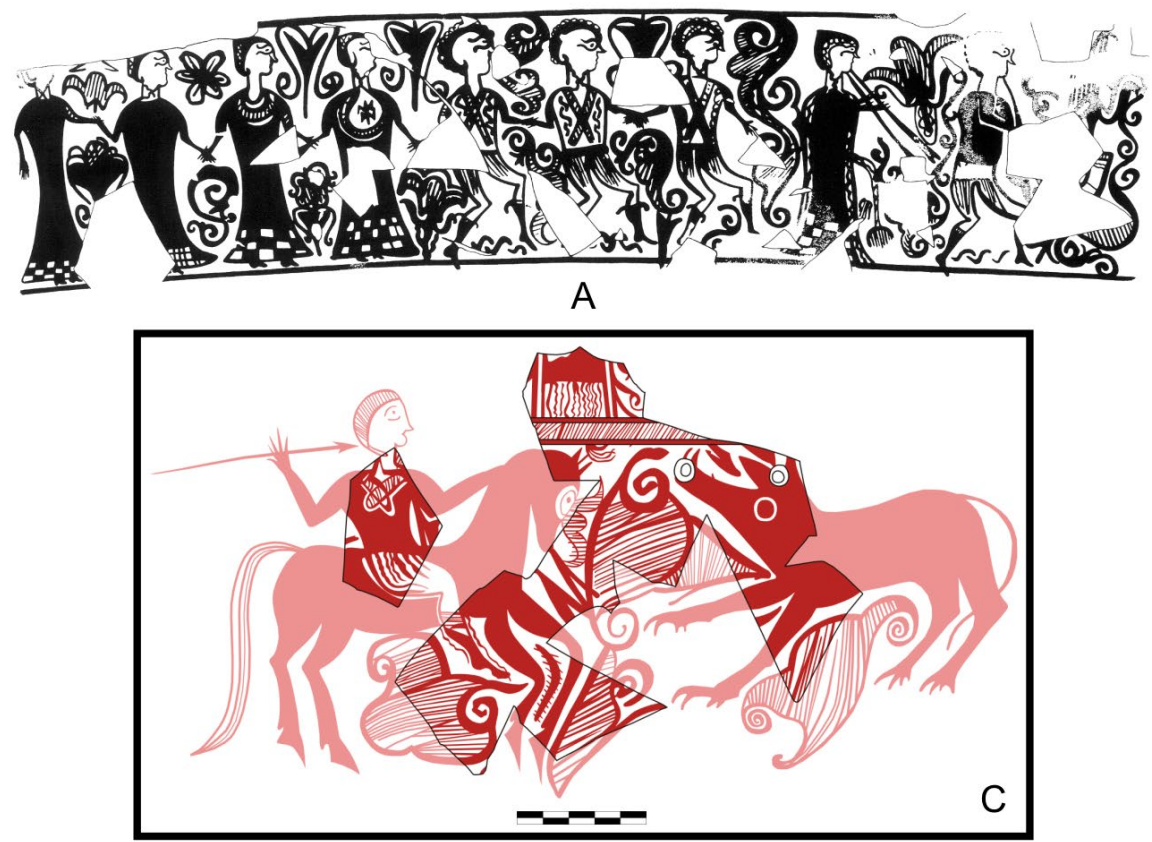

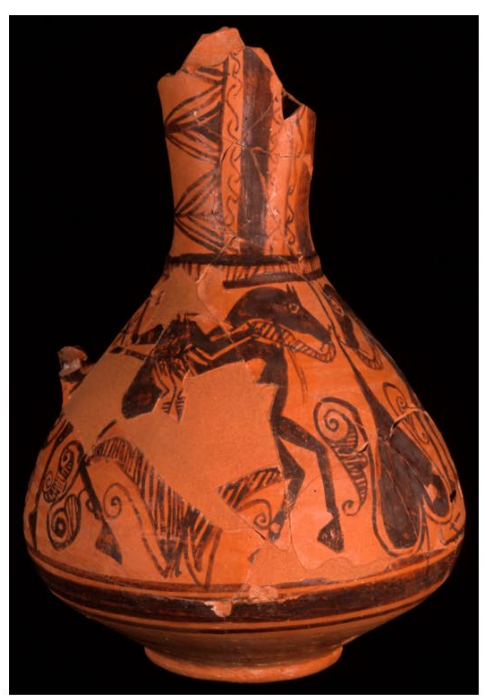

B

Figura 10: A. Escena de danza ritual sobre un kálathos del departamento 12 de Sant Miquel de Llíria (Bonet, 1995: fig. 26). B. Oinokhóe del Tossal de Manises (foto Archivo Gráfico MARQ). C. Reconstrucción de la decoración de un oinokhóe ibérico del Penyal d'Ifach. C. Oinokhóe del Tossal de Manises (foto Archivo Gráfico MARQ). 
Por otro lado, se intuye una cierta compatibilidad entre determinadas armas indígenas y las propias de las tropas republicanas (Quesada, 2006: 75 ss.), hecho que debió favorecer el aprovechamiento de las piezas requisadas a las comunidades sometidas por Roma y propiciar una fabricación local al servicio de las legiones, sobre todo en un periodo en que éstas tendrían una gran necesidad de equipamiento militar. El armamento de carácter defensivo debió sufrir sucesivas reparaciones, perdurando en el tiempo ciertos tipos y posibilitando asociaciones de armas diversas, lo que explicaría la curiosa combinación de elementos en el jinete del lágynos lucentino.

Este personaje luce además una especie de faldellín corto, un componente reconocible en la indumentaria tanto de jinetes como de infantes y no sólo en guerreros, como se aprecia en algunos vasos de Llíria (Bonet, 1995: 87, 100 y 176, figs. 25, 34 y 175, etc.) (Fig. 10A) o la Serreta (Fuentes, 2007: 109-110, fig. 45; Verdú, 2009: 78-79, fig. 9). Faldellines similares se identifican en otras piezas del Tossal de Manises, como sucede en un oinokhóe de fines del siglo III o inicios del II a. C. (Olcina, 2007a: 75; 2007b: 92, fig. 9; 2009a: 42; Verdú, 2007; 2009: 77, lám. 3; Pérez Blasco, 2014: 345-348, fig. 110, $\mathrm{n}^{\circ}$ 1) (Fig. 10B), al igual que en otro jarro procedente del Penyal d'Ifach (Calp) (Verdú, 2009: 71 y 79, fig. 2, láms. 1 y 2) (Fig. 10C), ambos buenos ejemplos del «estilo narrativo». Pudo ser una pieza habitual de la vestimenta, un auténtico faldellín plisado o compuesto por tiras de algún tejido similares a los pteryges o flecos de cuero de ciertas armaduras.

\subsection{LO EXCEPCIONAL: EL ROSTRO FRONTAL}

Se trata de una pequeña cabeza aislada de frente, hoy prácticamente desaparecida, con el rostro oval enmarcado, según Fernández de Avilés (1944: 161-162), por una cabellera de cortos mechones que abarcaría hasta el arranque del cuello, alto y seccionado en oblicuo. Las cejas son semicirculares y los ojos simples puntos. La nariz se indica con un trazo vertical y con otro horizontal la boca.

La aparición de rostros frontales en la cerámica ibérica no constituye un hecho muy común, coincidiendo todos ellos en la frontalidad, la falta de expresión y los errores de proporción y perspectiva. Suelen estar contorneados con trazos gruesos y oscuros, con los rasgos ejecutados esquemáticamente, transmitiendo un aire grotesco. Buena parte de estos rostros pintados se reconocen en el territorio contestano y el área turolense, destacando sobre todo en l'Alcúdia (Fernández de Avilés, 1944: 163 ss., figs. 2-3; Ramos Folqués, 1990: 162, lám. 65, figs. 108-110), donde son habitualmente femeninos y se interpretan como representaciones de una divinidad local de la naturaleza en esquema epifánico (Tiemblo, 1997: 16; 1999: 176 ss.), que simula brotar de la tierra (Ramos Fernández, 1991: 15 y 19;
1992-94: 128-130) y se manifiesta a los hombres (áno$d o s)$, con los que establece algún tipo de contacto. La frontalidad constituye un recurso estético que incide en esta idea de comunicación (Olmos, 1992: 307).

Entre los ejemplos seleccionados en la cerámica ilicitana destaca el conocido «Vaso de la Pepona» o «Tonta del Bote» (Fernández de Avilés, 1944: 169170, fig. 8; García y Bellido, 1944: 114-115; Ramos Fernández, 1991: 33-34, láms. II y III, nota 27; Tiemblo, 1999: 181-182, fig. 8, lám. III; Aranegui, 2000: 298-299, fig. 3) (Fig. 11A), así como el rostro de la cazoleta central de un kérnos (Page, 1984: 139-140, fig. 22, lám. IX, no 1; Olmos, 1987: 22-23, fig. 1; Ramos Folqués, 1990: 169-170, lám. 72; Ramos Fernández, 1991: 34-35, lám. IV; Tiemblo, 1999: 182, fig. 9) (Fig. 11B), un recipiente ritual en el que aparecen además aves, liebres, conejos y peces. Otro de estos rostros se plasma en una imitación de crátera augustea (Olmos, 1988-89: 91-93; 1992: 306-307; Ramos Fernández, 1991: 48-51, láms. XX y XXI; 1992; Tiemblo, 1999: 179, fig. 5, lám. II; Marín, 2000-01: 190, fig. 2; Tortosa, 2004: 102, foto 2; Ronda y Tendero, 2010: 331, fig. 7.1; 2014: 203 ss., fig. 4, $\mathrm{n}^{\mathrm{o}}$ 15; 2015: 265-267, figs. 2-4; Pérez Blasco, 2012: 147, fig. 22; Tendero et al., 2014: 234-235, fig. 7). También se registra en un fragmento procedente de las excavaciones efectuadas en 1967 en el Tossal de Manises (Fig. 11C), que evoca la representación de la «diosa domadora de caballos» (pothnia hippon) ilicitana (Blázquez, 1954: 211, fig. 23; Pericot, 1979: 87, fig. 109; Ramos Folqués, 1990: 162, fig. 109, lám. 66, $\mathrm{n}^{\circ}$ 1; Tortosa, 2004: fig. 89; 2006: 77, fig. 28; García-Gelabert y Blázquez, 2006: 95-96, figs. 10-11).

En el lágynos de Lucentum, sin embargo, no se representa un rostro grotesco sino una pequeña cabeza de aspecto naturalista, presumiblemente masculina, insinuando el movimiento ascendente de una hipotética deidad epifánica o un personaje no divino en actitud serena y atenta que observa la acción. En esta misma línea cabría citar un pequeño fragmento cerámico con parte de otro rostro frontal localizado en el santuario de la Malladeta (la Vila Joiosa) (Espinosa y Marcos, 2014: 112, fig. 126, n $^{\circ}$ 20) o una pátera hallada en Monteagudo (Murcia) (Fernández de Avilés, 1944: 172-173, fig. 12, lám. V, no 1) (Fig. 11D). En la necrópolis del Tolmo de Minateda se recuperó un fragmento cerámico con una posible cabeza cortada (Tiemblo, 1997: 14-15) además del ya citado con dos infantes de frente (Fig. 7E), datado por el contexto material entre mediados del siglo I a. C. y el cambio de Era (Abad y Sanz, 1995: 74, 77 y 81, fig. 1, no 8). Conviene mencionar además el reciente hallazgo en el santuario del Cerro de los Santos (Montealegre del Castillo, Albacete), de un nuevo fragmento con un rostro frontal entre un ave esquemática y un lobo o carnassier (Brotons y Ramallo, 2014: 344-347, figs. 1-2) (Fig. 11E), interpretado como una divinidad por el empleo de pintura blanca sobre la cara y su tocado en forma de corona torreada. También destacan los rostros de una pareja 


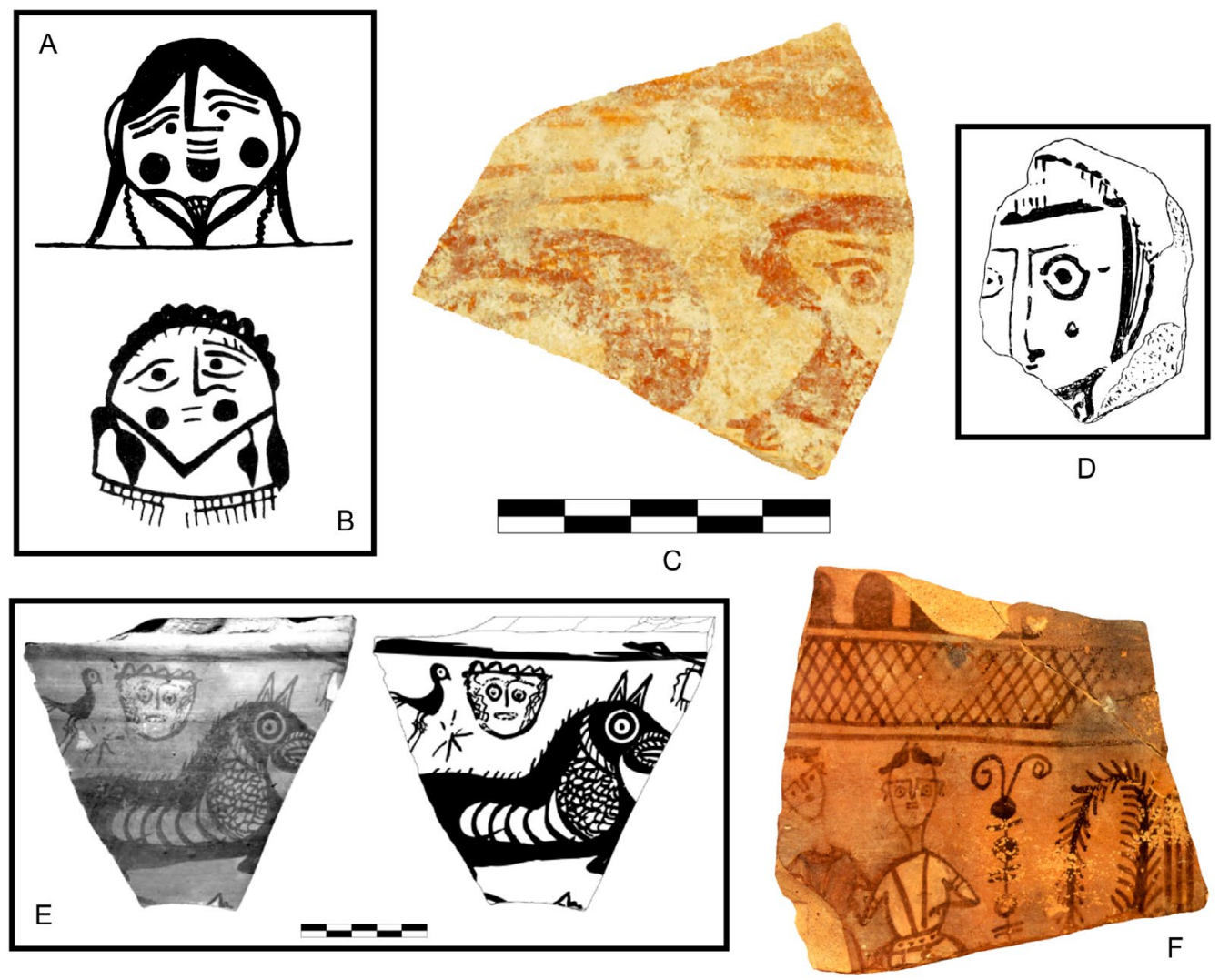

Figura 11: A. Rostro frontal del «Vaso de la Pepona» de l’Alcúdia (Fernández de Avilés, 1944: fig. 8). B. Rostro pintado de la cazoleta del kérnos ibérico de l'Alcúdia (a partir de Page, 1984: fig. 22). C. Fragmento decorado del Tossal de Manises CS 23441 (foto Archivo Gráfico MARQ). D. Fragmento de Monteagudo (Fernández de Avilés, 1944: fig. 12). E. Fotografía y dibujo de la decoración del fragmento del Cerro de los Santos (Brotons y Ramallo, 2014: figs. 1-2). F. Pareja representada sobre un fragmento cerámico de El Palomar de Oliete (Tiemblo, 1999: fig. 15).

de hombre y mujer pintados de frente en una pieza de El Palomar de Oliete (Teruel) (Maestro, 1983-84: 114, 116 y 118, fig. IID; 2013-14: 83, fig. 9; Beltrán, 1996: 134, fig. 123; Tiemblo, 1999: 185-186, fig. 15, lám. VI) (Fig. 11F), con el pelo partido en dos, cuello largo y rasgos esquemáticos, cuyas similitudes con el ejemplo alicantino quizás sean meramente formales.

\subsection{El ENTORNO NATURAL: LOS ANIMALES}

Los prótomos de aves con alas extendidas y cabezas giradas constituyen un motivo muy habitual en la cerámica ibérica decorada del sureste, apareciendo junto a otros animales y asociándose a la vegetación exuberante (García Hernández, 1987: 27-28; Mata, 2014: 70-73), con infinidad de ejemplos en l'Alcúdia (Ramos Folqués, 1990: 145 ss.; Sala, 1992: 32 y 55, figs. 10, 29, 69 y 70; Pérez Blasco, 2014: 530-533, fig. 144) (Fig. 12A y B), Tossal de Manises, Tossal de la Cala o El Monastil (Elda) (Poveda, 1988: figs. 28-29; Poveda y Uroz, 2007: 132, figs. 16 y 17; Uroz, 2008: 73-76). Se aprecia en estas aves una actitud independiente con respecto a otros elementos, hecho particularmente significativo en este caso al disponer de un espacio exclusivo, estando ausentes en la escena principal. $\mathrm{Su}$ posición más elevada alude quizás a su condición de animales del aire.

La especie concreta de estos seres es difícil de precisar puesto es un ave ideal, genérica, con cuello y piernas de águila y largo pico de ibis o grulla (Nordström, 1968: 97 y 103-109; García Hernández, 1987: 16-17; Olmos, 1988-89: 90). Las alas pueden perder contacto con el cuerpo, mostrándose de perfil o medio perfil, y se aplican «filigranas» en el cuello en forma de retículas o rallados. En algunos casos se representan en tinta plana, como sucede en el vaso del Tossal de Manises, donde configuran una secuencia de tres individuos sin solución de continuidad.

Habitualmente se relacionan con la idea de la protección de la vida, en oposición al lobo (Aranegui, 2012: 176), el cual dispone también de un marcado simbolismo (Chapa, 1980: 914 y 926; Almagro-Gorbea, 1996: 108 ss.; 1999: 25 ss.; Mata, 2014: 125 ss.; Pérez Blasco, 2014: 539 ss.). La importancia de este animal totémico en el imaginario de los iberos se manifiesta en su reiterada aparición desde los mismos orígenes de esta cultura (Mata y Soria, 2012: 54 ss.), sobre todo en las decoraciones ilicitanas (Fig. 12A y C), y se le considera un ser mítico de carácter maligno. Asociado al guerrero por su fiereza y astucia, se le relaciona además con la noche y la muerte, con los ritos 

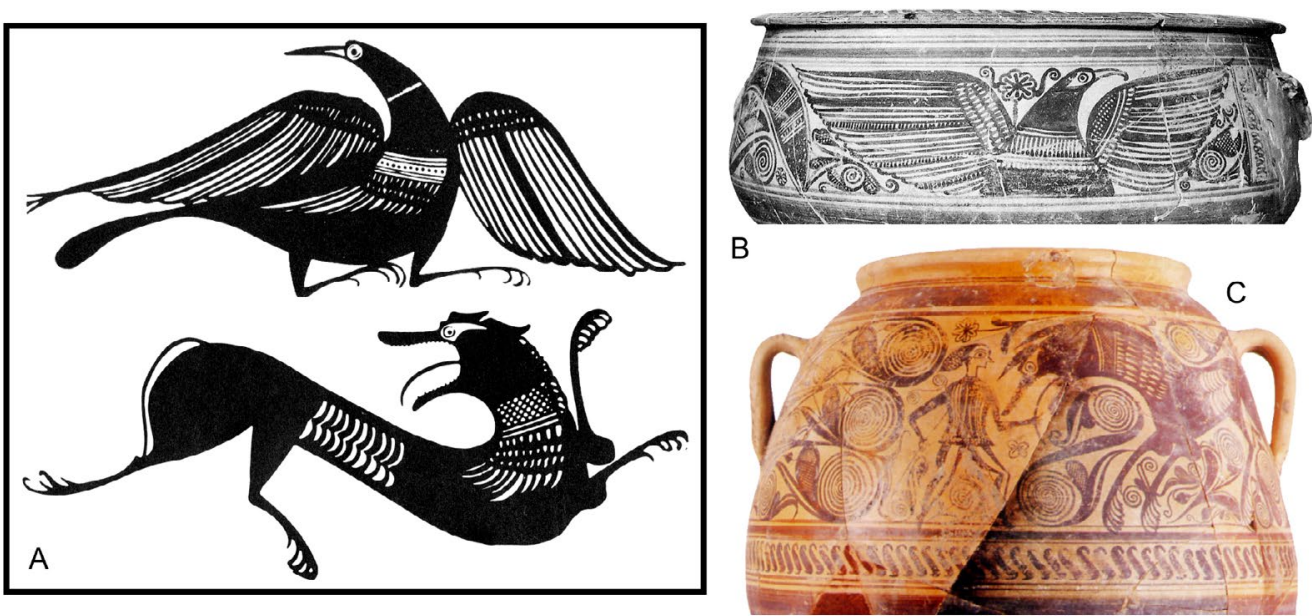

Figura 12: A. La imagen del ave y el «carnicero» en la cerámica ilicitana (García Hernández, 1987: 15 y 17). B. Gran lébes decorado de l'Alcúdia (Ramos Folqués, 1990: lám. 51). C. Tinaja con representación de un gran lobo de l'Alcúdia (foto Fundación Universitaria «La Alcudia» de Investigación Arqueológica).

de iniciación y de tránsito, ejerciendo de guardián de las sepulturas o como personificación de una divinidad infernal. Al igual que el jabalí, es un animal muy frecuente en los bosques mediterráneos (Mata et al., 2013: 192) y goza de un sentido más popular y menos aristocrático (González y Chapa, 1993: 169 ss.).

Los «carniceros» son también animales ideales, con rasgos de león y de lobo (García Hernández, 1987: 17; Sala, 1992: 114), aunque se estima una mayor semejanza con el segundo, buscando plasmar el concepto de un ser terrorífico, hambriento y devorador (Olmos, 1988-89: 89; Verdú, 2009: 80), de ahí las fauces inmensas, los dientes, las garras y la representación geometrizada de las costillas, con lo que quizás también se busca alcanzar una sensación de mayor volumen. Estos rasgos se constatan en el lágynos, donde la figura del lobo se registra tanto en el cuello como en la escena principal, atacando al jinete ${ }^{17} \mathrm{o}$, si se interpreta la imagen en clave funeraria, acompañándole al «más allá».

Los cuadrúpedos acechados por el lobo podrían catalogarse como ciervos, si bien se plasman de una manera un tanto libre ${ }^{18}$, y a partir de ciertos rasgos es posible distinguir entre machos y hembras (Mata, 2014: 19 ss.). En los primeros el cuerpo es esbelto, en el cuello se aprecia el pelaje y destacan sobre todo sus desarrolladas defensas, para las que apenas hay espacio. Entre los dos individuos masculinos se sitúa una hembra, con cuerpo más ancho, sin cornamenta y con largas orejas similares a las de los lagomorfos. Las patas son siempre delgadas, con las articulaciones

17. Como sucede en este caso, cuando se enfrentan a hombres los lobos suelen representarse justo en el momento previo en que ambos entrarían en contacto (Mata, 2014: 130).

18. Al igual que ocurre en la escultura (Chapa, 1980: 890), los cérvidos no suelen presentar rasgos bien definidos, acentuándose su cornamenta, símbolo de belleza y poder fecundante en la Antigüedad (Olmos, 2001-02: 208). dobladas señalando movimiento e intuyéndose las pezuñas, la cabeza se reduce al círculo del ojo, con punto central, y a partir de ésta se representa un largo morro con remate encorvado.

Las imágenes de cérvidos son más frecuentes en la cerámica bastetana que en la Contestania, manifestando un carácter sagrado entre los iberos ${ }^{19}$ vinculado a la fertilidad y al «más allá». Se relacionan además con el devenir cíclico de la vida, lo que podría tener sentido en la representación del Tossal de Manises, donde siguen una misma dirección, y se les asocia con las élites aristocráticas y la caza, una de sus principales actividades $^{20}$ (Aranegui, 2012: 195-196; Mata, 2014: 169-171, figs. 279-280). Su aparición en estas escenas tendría una intención esencialmente narrativa, como sucede en los grandes pithoi del Tossal de Sant Miquel (Fig. 13A), en los que figuran ciervos con y sin notables cornamentas (Bonet, 1995: 114, 172 y 179, figs. 42-44, 84 y 88). También se reconocen potentes astas en los individuos pintados sobre un kálathos de Cabecico del Tesoro (Tortosa, 1998: 214, fig. 8) o en el ejemplar masculino del «Vaso de las Cabras» de la tumba 80 (Nieto, 1939-40: lám. III; Olmos, 2001-02: 206 y 208, figs. 1-2, láms. 1-2; Pérez Blasco, 2014: 395-398, fig. 117, no 14-17). El estilo degenerado de los ciervos del vaso de Lucentum es similar al de algunas cerámicas de Azaila con imágenes de cacería (Cabré, 1944: 20 y 67-70, figs. 47 y 56, láms. 33-35; Maestro, 2010: 224-225, figs. 8-9) (Fig. 13B), fechadas en pleno siglo I a. C. Aparecen en un kálathos de

19. El ciervo debió tener un carácter ritual desde época preibérica, como lo demuestran sus representaciones en jarros, thymiatéria y figuras de bronce orientalizantes (García-Gelabert y Blázquez, 2007: 92 ss., figs. 7-16).

20. Al igual que otras especies salvajes como el jabalí, los ciervos formarían parte de la caza mayor, siendo las presas esenciales, como también lo fueron entre las élites europeas de la Edad Media (Mata et al., 2013: 186). 

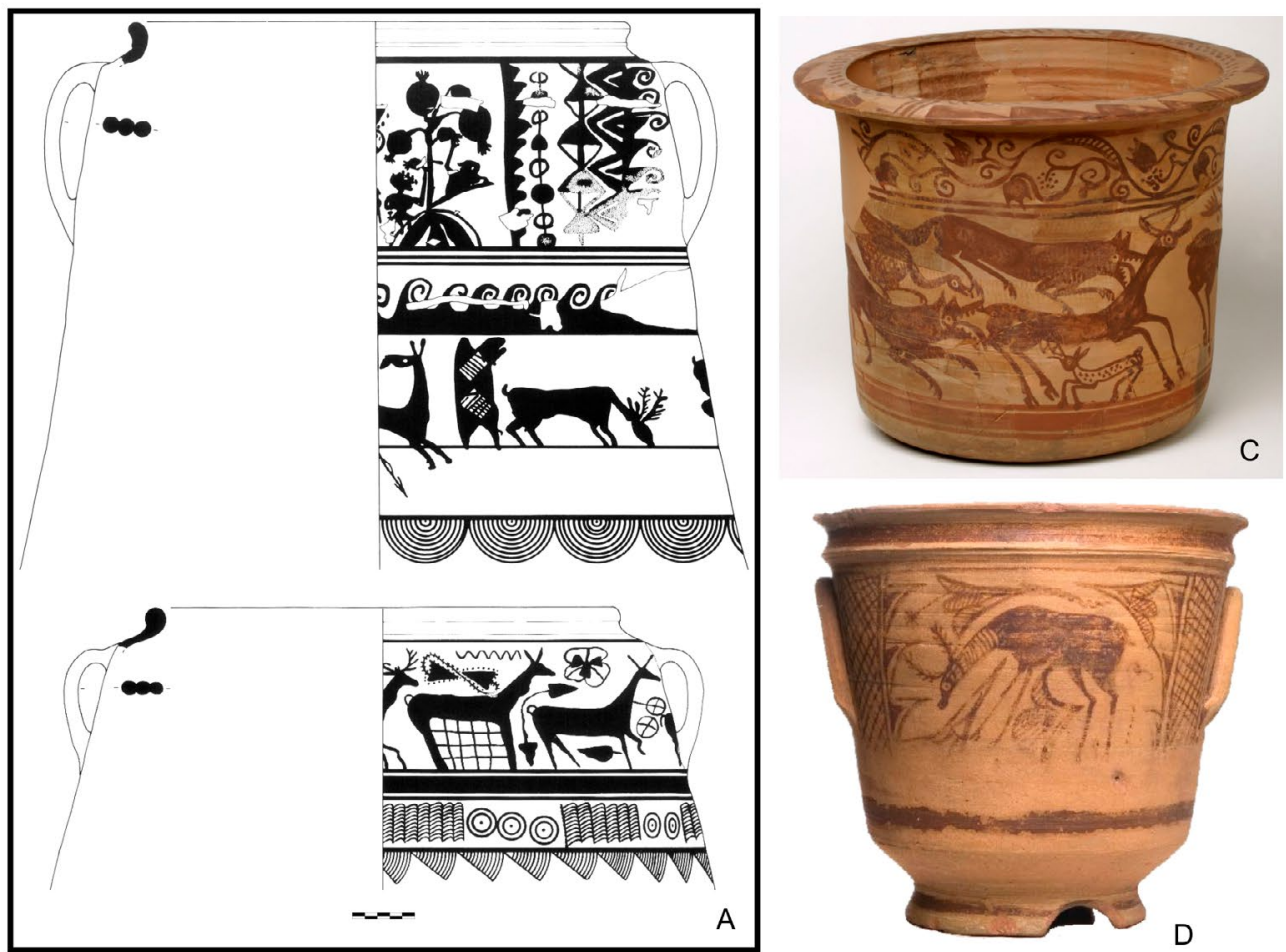

A
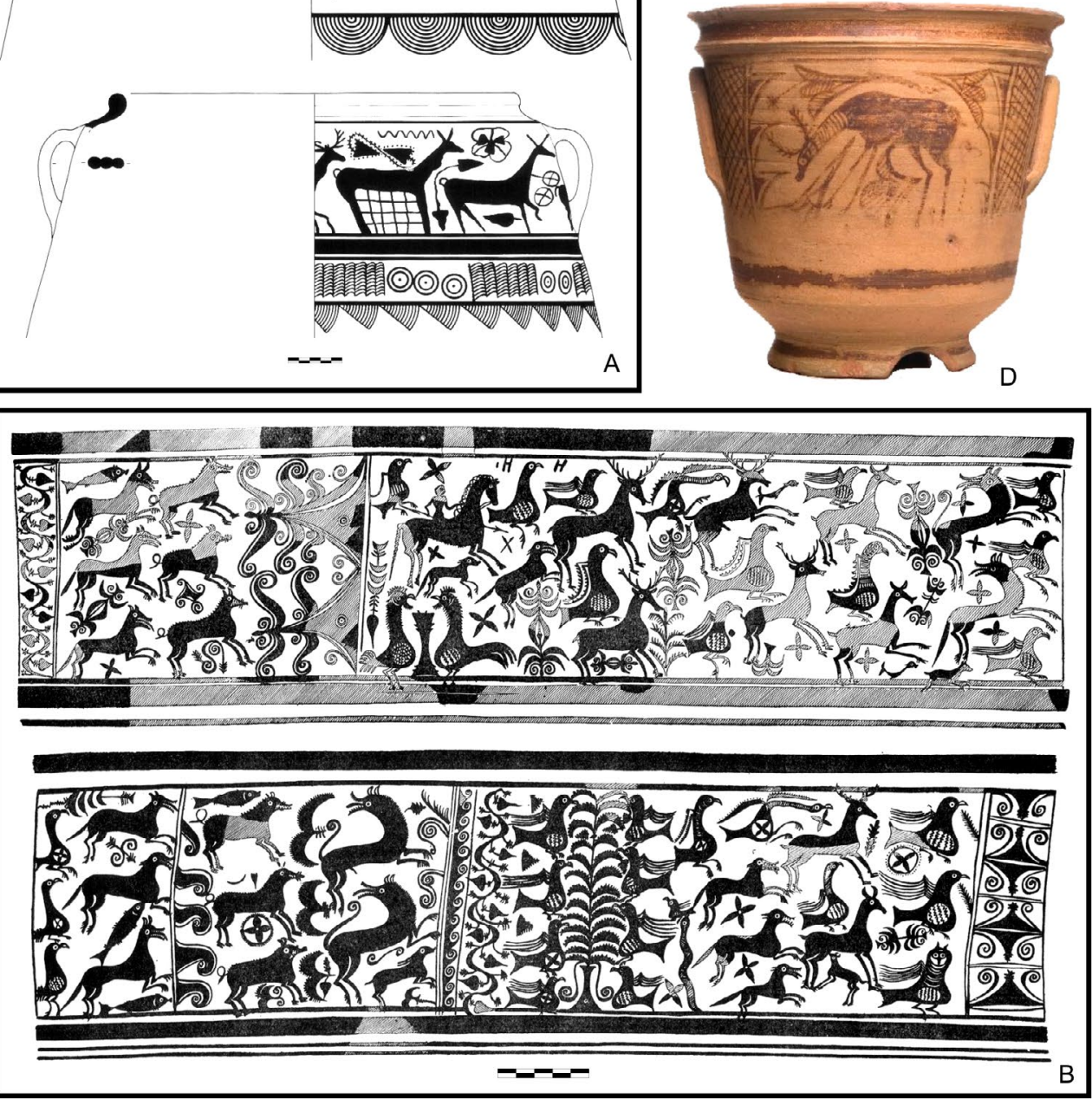

Figura 13: A. Detalle de la decoración de dos tinajas del departamento 15 del Tossal de Sant Miquel de Llíria (a partir de Bonet, 1995: figs. 42-43). B. Desarrollo de las escenas pintadas sobre dos cerámicas de Azaila (Cabré, 1944: figs. 47 y 56). C. Kálathos decorado con ciervos de Azuara (foto Museo Arqueológico de Zaragoza). D. Ciervo pintado sobre un vaso crateriforme de la necrópolis del Tolmo de Minateda (foto Museo de Albacete).

la Cueva del Cabuchico (Azuara, Zaragoza) (Beltrán, 1996: 104, fig. 91; Olmos, 2001-02: 212-213, láms. 3-4) (Fig. 13C) y en El Castellito (Alloza, Teruel) (Maestro, 2010: 220-224, fig. 5). Aves y ciervos coinciden también en el «Vaso de los Guerreros» de la Serreta (Olmos y Grau, 2005: 93). Otras representaciones de ciervos se constatan en Libisosa (Uroz, 2012: $310-312$, 339 y 365-371, figs. 241 y 276a), el Tolmo de Minateda (Abad y Sanz, 1995: 73, 77 y 79, fig. 1; Sanz, 1997: 50, fig. 20; Tortosa, 2006: n 338, lám. 99;
Pérez Blasco, 2014: 815 y 817, fig. 199, no 1-4) (Fig. 13D) y en un pithiskos del Tossal de les Basses (Rosser y Fuentes, 2007: 65 y 112). En estos dos últimos ejemplos el ciervo ocupa la escena central, mientras que en el lágynos del Tossal de Manises estos seres ceden el protagonismo al jinete, transmitiendo al igual que éste un pronunciado movimiento.

Haciendo gala del horror vacui característico de este tipo de decoraciones, el espacio comprendido bajo el lobo y los dos ciervos masculinos se encuentra 


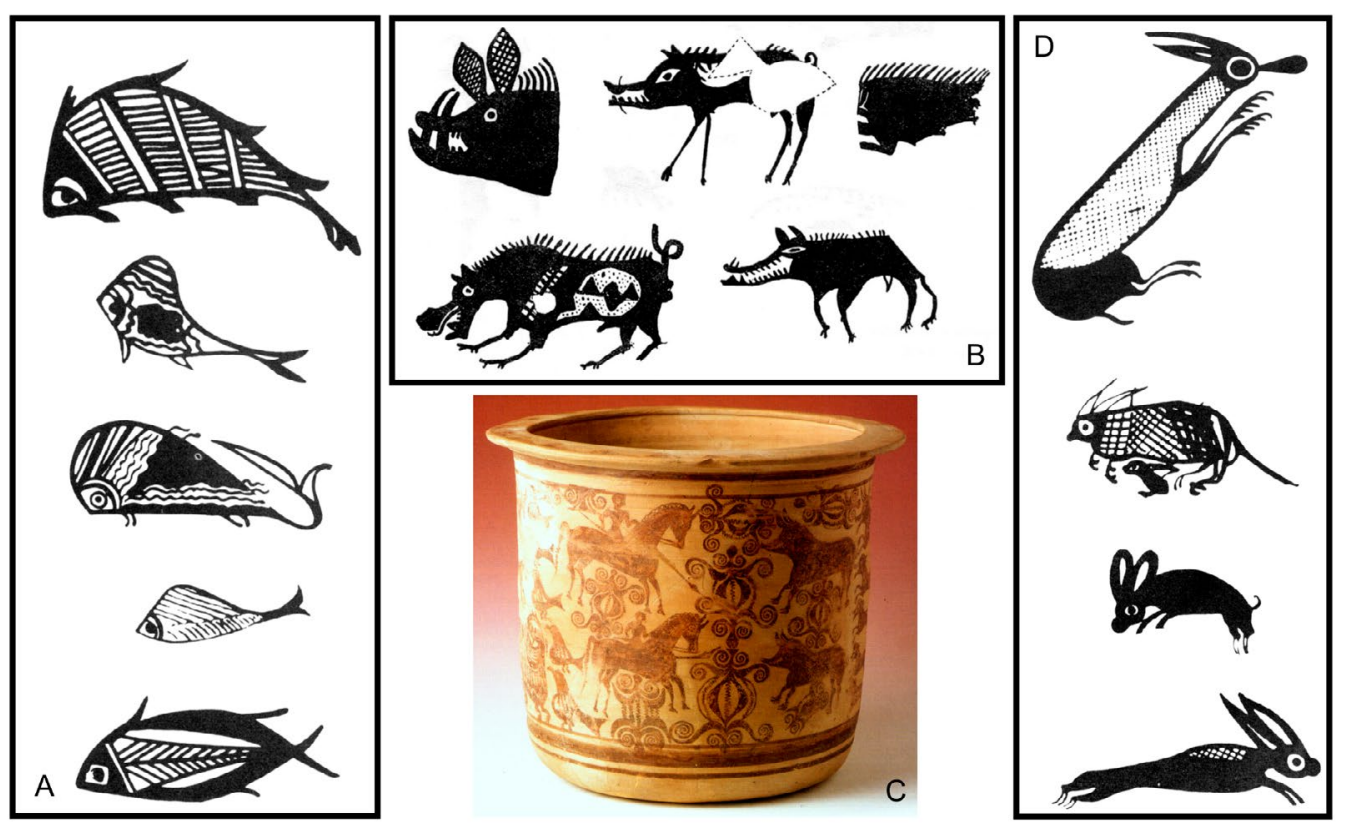

Figura 14: A. Diversos peces representados en las cerámicas de l’Alcúdia (García Hernández, 1987: 19). B. Jabalíes identificados en el Tossal de Sant Miquel (a partir de Ballester et al., 1954: 123). C. Kálathos con escena de cacería de La Guardia de Alcorisa (Beltrán, 1996: fig. 76). D. Lagomorfos pintados en cerámicas ilicitanas (García Hernández, 1987: 19-30).

ocupado por peces. Éstos no parecen disponer de un rol destacado en los vasos cerámicos, como suele suceder en las piezas de Edeta o l'Alcúdia (Mata, 2014: 9598), aunque lo cierto es que su aparición, como la de otros elementos presentes en este vaso, no sería banal, y se integrarían plenamente en el código iconográfico, contribuyendo a definir el escenario en el que transcurre la acción al situarse sobre una cenefa de postas susceptible de representar un curso de agua. Los peces son relativamente frecuentes en las cerámicas ilicitanas (Ramos Folqués, 1990: 157, figs. 90-93, láms. 60-61) (Fig. 14A), localizándose en los espacios libres generados por otros seres, con una amplia variedad estilística. El poco interés por reproducir su aspecto real lleva al artesano a ejecutarlos con rasgos sencillos y estereotipados, generalmente con un cuerpo arqueado, con el interior rallado o reticulado y de la cabeza sólo se aprecia el ojo con un gran punto (García Hernández, 1987: 19; Sala, 1992: 115), características observables en el vaso lucentino.

Menos habituales son las imágenes de jabalíes en Iberia pese a su estrecha relación con la práctica de la caza y el «más allá» en todo el Mediterráneo antiguo (Chapa, 1980: 920-923; Prieto y López, 2000: 46 y 49; Pérez Blasco, 2014: 148-149). Símbolos de fuerza y valor, su interpretación es sencilla y su imagen se encuentra bastante normalizada (Mata, 2014: 23 ss.). Suelen aparecer atacando a sus propias presas o en plena huida, esencialmente en cerámica y objetos de orfebrería como las fíbulas de plata o la conocida pátera de Tivissa (Quesada, 1997: 119). Por otro lado, al igual que ocurre con la figura del lobo, cabría la posibilidad de valorar al jabalí como un emblema heráldico del propio guerrero, cuyas atribuciones podrían ser tanto beneficiosas como malignas. Ambos cuentan con un simbolismo infraterrenal en la iconografía ibérica, siendo fieras nocturnas y salvajes de carácter monstruoso propias del mundo subterráneo (Mata et al., 2013: 185).

Escenas con jabalíes se constatan en las cerámicas de Llíria (Bonet, 1995: 135, figs. 61 y 63, n 346; Pérez y Mata, 1998: 238, fig. 4, $n^{\circ}$ 3) (Fig. 14B), destacando también la cacería representada en el «Vaso de los Guerreros» de Archena (Fernández de Avilés, 1943: 115; Olmos, 1987: 28 ss., figs. 6-11; García Cardiel, 2014: 162-163, fig. 1), en la que aparece también un jinete lancero. Escenas de caza de jabalíes y ciervos se registran igualmente en ciertos vasos de $\mathrm{Ca}$ bezo de Alcalá de Azaila o Cabezo de La Guardia de Alcorisa (Cabré, 1944: 19-20; Pellicer, 1970; Beltrán, 1976. 283; 1996: fig. 76; Tiemblo, 1999: 183-185, fig. 12-14; Maestro, 2010: 219 ss.; 2013-14: 76 y 79, figs. 2-3) (Fig. 14C), todos ellos de entre fines del siglo II y comienzos del I a. C. Más problemática es la identificación de la enorme bestia a la que se enfrenta un jinete en el ya citado oinokhóe ibérico del Penyal d'Ifac (Verdú, 2009: 80, fig. 1, lám. 1).

La presencia de liebres y/o conejos saltando o agazapados ayuda a contextualizar el ambiente cinegético, siendo los lagomorfos muy frecuentes en las decoraciones cerámicas (Mata, 2014: 28-30), en las que suelen interpretarse, al igual que los peces, como un motivo secundario, simbolizando respectivamente la tierra y el agua (Olmos, 1988-89: 90; Ramos Fernández, 1991: 27). Existen infinidad de representaciones de conejos en la cerámica de l'Alcúdia (Ramos Folqués, 1990: 159, figs. 94-96, láms. 62-63, etc.) (Fig. 14D), definidos por su pequeño formato y 
esquematismo, cuerpo ovalado con el interior macizo o reticulado, patas terminadas en garfios, corta cola, cabeza circular con un punto central señalando el ojo, orejas largas y puntiagudas y hocico también representado por un simple punto (García Hernández, 1987: 20; Sala, 1992: 116), como se aprecia en el lágynos del Tossal de Manises.

El caballo es el único animal doméstico plasmado en este vaso, contando con un indiscutible simbolismo tanto en la Cultura Ibérica como en todo el ámbito indoeuropeo y mediterráneo (Almagro-Gorbea, 2005: 152 ss.; García-Gelabert y Blázquez, 2006; Mata, 2014: 35 ss., entre otros). Dotado de aspectos ctónicos y psicopompos, se vincula con la divinidad y el «más allá», así como con ritos de paso y de iniciación (Almagro-Gorbea y Torres, 1999: 79; Prieto y López, 2000: 47-48), con la imagen del guerrero fallecido y posteriormente heroizado (Quesada, 1998: 171-172; Verdú, 2009: 74-75) y sobre todo con las élites ecuestres. Su importancia como animal de monta entre los iberos es fundamental, de ahí que se representen enjaezados y cabalgados por jinetes, no tanto de manera aislada, o libres en entornos naturales (Mata, 2014: 44 y 205).

Convendría preguntarse, puesto que no es posible defender a partir de las evidencias arqueológicas la existencia de una auténtica caballería ibérica, quiénes serían los personajes a caballo de estas decoraciones cerámicas $^{21}$, asunto especialmente interesante al tratarse de piezas halladas en contextos de plena conquista romana. Se trataría de contingentes militares surgidos y condicionados por las exigencias de potencias extranjeras. En este sentido, pese al reclutamiento de efectivos por parte de los cartagineses a partir de inicios del siglo III a. C. (Quesada, 1998: 178; 2002-2003, 85), el impulso decisivo en la formación de tropas auxiliares a caballo se debería a la participación de las élites locales al servicio de Roma (Almagro-Gorbea, 1995b: 249-250). Por otra parte, el que las representaciones de estos guerreros coincidan cronológicamente con episodios bélicos destacados (sea el enfrentamiento entre Roma y Cartago o las guerras civiles del I a. C.), en los que participan auxiliares como los mercenarios celtíberos, nos hace pensar en que quizás los individuos retratados, si es que en realidad se trata de retratos, no sean jinetes ibéricos.

\subsection{Completando La esCenogRafía: MOtivos GeO- MÉTRICOS Y VEGETALES}

Estos elementos quedan relegados en el lágynos a un segundo plano, sirviendo básicamente como

21. W. Kurtz (1992: 213) estima que la relativa abundancia de jinetes armados se debería a razones pictóricas o simbólicas, no siendo su participación real de un gran valor estratégico a la hora de combatir. delimitadores de espacios. Para el caso de los geométricos, se suceden siempre en estrechas franjas horizontales enmarcadas por líneas. Esto es así, en primer lugar, en la secuencia de SSS, gruesas y cortas, que ocupa la parte superior del cuello, siendo éste un elemento propio de la cerámica ilicitana hasta la primera mitad del I d. C. (Ros, 1989: 68-69), registrándose tanto de manera aislada como formando pequeños grupos de trazado horizontal o vertical (García Hernández, 1987: 22). En ocasiones se ha propuesto que estas SSS servirían para indicar movimiento o incluso la emisión de sonidos, como parecen sugerir escenas como el desfile de soldados y músicos de un vaso de El Cigarralejo (Cuadrado, 1982) o ciertas cerámicas de Llíria (Pastor, 1998; 2010). En l'Alcúdia, largas series de SSS simples delimitan metopas con decoración figurada en el punto de mayor diámetro de los vasos o aparecen en los cuellos de algunos de ellos (Santos, 2010: 158 y 162), como en la pieza de Lucentum, pudiendo considerarse quizás como un «comodín polisémico» en el lenguaje de las decoraciones sobre cerámicas ibéricas (Uroz, 2013: 66), con diferente significado según la escena y el contexto, posición y morfología.

También se distingue en el lágynos una estrecha cinta con grupos de líneas verticales paralelas a modo de triglifos. Este tipo de trazos en grupo suele aparecer tanto en la zona de unión del cuello y el cuerpo como en la media-inferior de éste (Ros, 1989: 70), y parecen ser el precedente de uno de los motivos geométricos más habituales en las producciones augusteas de «tradición indígena» (motivo Ros A.11.2), con numerosos ejemplos en el propio Tossal de Manises o en la necrópolis del Parque de las Naciones (Rosser, 1990-91: 91, fig. 5a).

En la base del cuello figura una cenefa de postas o roleos, a los que se suele asignar una función meramente decorativa, con un sentido de eternidad o bien se reconoce en ellos la superficie del mar (Aranegui, 2000: 300). Estas espirales pueden combinarse con otros elementos vegetales y ya se constatan en las cerámicas de Llíria junto a series de SSS (Bonet, 1995: figs. $122,125, n^{\circ} 510,132, n^{\circ} 465$, etc.). Están sobradamente representados en l'Alcúdia, apareciendo una secuencia de postas en el conocido «mosaico helenístico» (Fig. 15), considerado como una obra local inspirada en modelos suritálicos, fechado entre fines del siglo II e inicios del I a. C. (Ramos Folqués, 1975; Abad, 1986-87: 97-104; Lara, 2007). También se registran roleos en un olpe de asa trenzada de La Escuera (San Fulgencio) (Nordström, 1967: 36 y 42, fig. 29, lám. IXb; 1973: fig. 20, nº 9, lám. 14, n 3; Llobregat, 1972: lám. XI; Pericot, 1979: 58; Tortosa, 2006: nº 103, lám. 22), de fines del III a. C., así como en un fragmento de vasija de gran formato de la villa romana de la Calle Rómulo (Pérez Burgos, 1994: 58-59, fig. 20; Tortosa, 2006: n 222 , lám. 57), muy próxima a Lucentum. En la Serreta suelen ocupar el cuello de los oinokhóai, el borde de platos o las esquinas de algunas tapaderas 


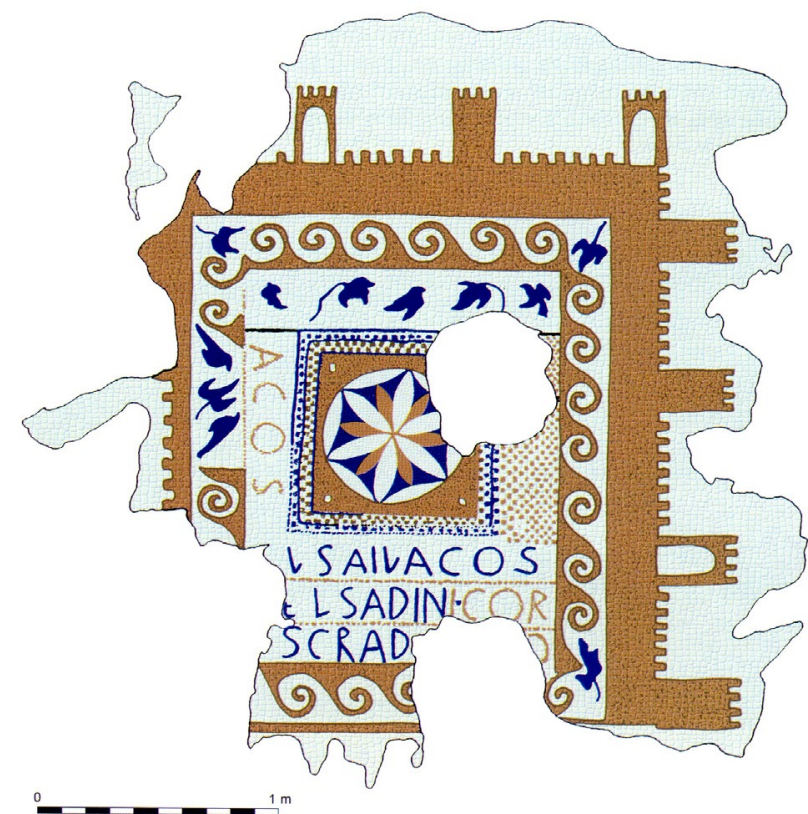

Figura 15: El denominado «mosaico helenístico» de l’Alcúdia (tratamiento gráfico de Á. Sánchez, publicado en Bonet y Ribera, 2003: 81).

de cajitas cerámicas (Fuentes, 2006: 39, figs. 8 y 24; 2007: 47 y 68-69, fig. 10).

Las series de SSS, postas, aspas, reticulados, etc., son frecuentes en las cerámicas ibéricas del sureste, planteando un problema de interpretación al encontrarse muchas veces a medio camino entre lo puramente geométrico y la estilización vegetal (Santos, 2010: 154-155). En ocasiones se identifican en otro tipo de soportes ${ }^{22}$, transmitiendo quizás mensajes universales reconocibles, como ocurriría con las postas y su similitud con las olas del mar.

En la pieza del Tossal de Manises apenas se intuyen motivos vegetales, sirviendo en cualquier caso como elementos de relleno distribuidos de manera aleatoria y siendo difícil clasificar la especie botánica (Tortosa, 1996: 178-179). Bajo la secuencia de prótomos de ave aparecen unos tallos curvos simulando flores de loto $\mathrm{u}$ hojas esquemáticas, si bien no se puede descartar que sean las patas de dichas aves. Si optamos por la primera opción, se trata de un recurso de evidente origen oriental pero que también forma parte del imaginario ibérico, como demuestran, por ejemplo, las escenas talladas sobre el monumento funerario de Pozo Moro (Blech, 1996: 198, figs. 1 y 2). El resto de elementos vegetales constatados, con excepción de una pequeña voluta sobre el lobo de la escena principal, se identifican en el friso de los cérvidos: tras el «carnicero» una

22. Es posible reconocerlas, por ejemplo, en la cresta de hierro de un casco de la tumba de carácter principesco 277 de El Cigarralejo (Cuadrado, 1968: 169 y 174-175, fig. 21, $\mathrm{n}^{\mathrm{o}} 1$; 1987: 92 y 474, fig. 103, n 19, lám. XXII) o sobre el puente argénteo de la Fíbula Braganza (Perea et al., 2007: 20). doble espiral, similar al brote que separa la segunda y tercera presa, corto y rematado por sencillas volutas, y bajo el cuerpo del primer ciervo y entre las patas delanteras del animal que lo precede sendas espirales que contribuyen a enmarcar la escena, sin pretensión alguna de plasmar la realidad fielmente (Mata et al., 2010: xiii y 128-131), en un ambiente de naturaleza exuberante y fecunda.

\section{VALORACIÓN GENERAL Y CONTEXTUA- LIZACIÓN HISTÓRICA}

La rica decoración que muestra este lágynos le confiere un carácter de «vaso singular» ${ }^{23}$, sólo al alcance de unas élites dirigentes inmersas en estos momentos en un ambiente de presencia efectiva romana. Debieron ser piezas con una circulación restringida, localizándose en ocasiones en espacios dotados de un carácter igualmente singular ${ }^{24}$, si bien pudieron ser objeto del comercio, apareciendo algunas de ellas fuera de su ámbito comarcal. Por otra parte, este hallazgo suscita un nuevo interrogante: ¿qué sentido tendría un vaso con iconografía de idealización de un guerrero «ibérico» en la casa de un magistrado romano?

Para decorar estas cerámicas de prestigio, verdaderos soportes de transmisión de códigos identitarios, se recurre al imaginario propio de la Cultura Ibérica (Grau, 2005: 110 y 116). Las élites hispanorromanas, herederas de las antiguas aristocracias indígenas, buscarían para legitimarse referentes simbólicos universales incuestionables por los miembros de su comunidad (Aranegui, 2012: 325-326; García Cardiel, 2014: 160 ss.), si bien ya no tendría sentido retratarse combatiendo entre sí como sucedía en el siglo III a. C. Es por ello que aparecen enfrentándose en solitario, habitualmente a caballo, a un mal menos definido con el aspecto de grandes lobos o animales híbridos, apelando a un lenguaje iconográfico de carácter épico (Santos, 2010: 148; Uroz, 2013: 52). El ibero «reelabora» así sus imágenes a partir de unos elementos reconocibles a grandes rasgos, aunque resulta complejo precisar, por ejemplo, si los personajes son seres

23. Este concepto alude a un tipo de producción alfarera alejada de las series ordinarias, tratándose con total seguridad de vasos realizados por encargo (Olmos, 1987; Aranegui, 2012: 272), atesorados como bienes de prestigio de elevado valor.

24. En el reciente estudio sobre el denominado «Kálathos del Gallo» del Tossal de Manises, otra cerámica con una excepcional decoración, se ha apuntado que podría tratarse de un hallazgo acontecido en el interior de una capilla doméstica o una estancia reservada al culto urbano (Pérez Blasco, 2012: 145). En este mismo sentido, vasos ricamente decorados de Llíria y de la Serreta aparecieron en departamentos interpretados como viviendas aristocráticas o espacios sacros, indicando que sus propietarios debieron ser individuos destacados de la comunidad (García Cardiel, 2014: 165). 

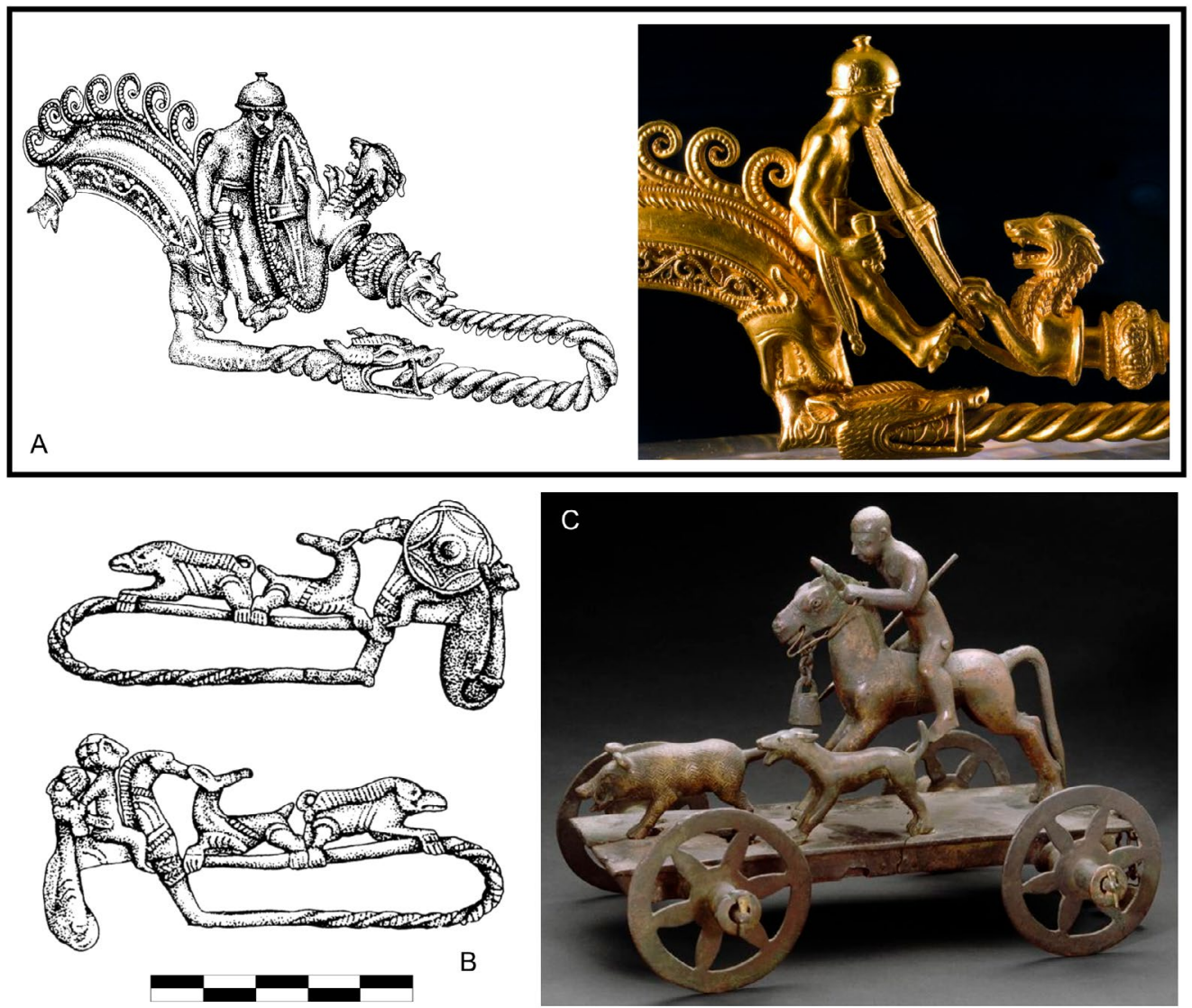

Figura 16: A. Dibujo y detalle del infante de la Fíbula Braganza (Lenerz-De Wilde, 1991: fig. 115, nº 2; Perea et al., 2007: 16). B. Fíbulas argénteas de Cañete y Chiclana (Almagro-Gorbea y Torres, 1999: lám. 12, nº 2 y 3). C. Carro votivo de bronce hallado en Mérida (foto Musée des Antiquités Nationales de Saint-Germain-en-Laye).

divinos, aristócratas o guerreros míticos. Lo más probable es que se narren escenas ideales, alusivas a un pasado legendario y modélico (Olmos, 2000: 351), en el que se fundamentan los nuevos linajes y que aún tienen su lugar en un ambiente ecléctico y de cierta «flexibilidad cultural».

Estos argumentos, no obstante, parecen entrar en contradicción con la escasez de elementos pertenecientes al dominio del caballo, básicamente bocados y espuelas, constatados tanto en poblados como en contextos funerarios (Quesada, 1998: 174, tabla 1; Verdú, 2015: 338-341), lo que redunda en su carácter exclusivo y diferenciador y sugiere que, quizás, no sean jinetes ibéricos los individuos que se observan en estas cerámicas.

Con la conquista y el inicio del control romano de Iberia $^{25}$ se produce un afianzamiento de los equites como élites al frente del gobierno de las ciudades. Interesados en justificar estatus y riqueza, se refuerza su vínculo con los talleres artesanales especializados, cuya actividad se incrementa, proliferando los pintores locales, los cuales ofrecen una nueva iconografía que refleja sus costumbres y creencias (Pérez Blasco,

25. Conviene destacar al respecto las recientes aportaciones por parte de C. Aranegui (2012: 309 ss.).
2014: 199 ss.) y suponen el mejor testimonio de la categoría de estas ciudades (Aranegui, 2007: 173). En esta nueva iconografía destacará el símbolo del guerrero a caballo (heros equitans), trasunto de una nobleza que reafirma su autoridad mediante un discurso de carácter mítico, igualmente visible en las emisiones monetales (Arévalo, 2003: 70; Verdú, 2009: 81-82). Las cabezas representadas en los anversos, por otra parte, deben corresponder a la principal divinidad local o al héroe fundador de la ciudad o del grupo social (Almagro-Gorbea, 1995b: 240 y 246; Almagro-Gorbea y Torres, 1999: 93-96; Gozalbes, 2006: 121-122). Resulta interesante comprobar que en el lágynos del Tossal de Manises aparece tanto un jinete lancero como un rostro humano de frente, elementos también presentes en otros soportes como las fíbulas argénteas (Almagro-Gorbea, 2005: 171 ss., figs. 14-16).

En la ya citada Fíbula Braganza o «Flannery brooch» (Fig. 16A), un broche de oro y esmalte fechado en el siglo III a. C. (Lenerz-De Wilde, 1991: 157, fig. $115, \mathrm{n}^{\circ} 2$; Prieto y López, 2000: 59, fig. 9, $\mathrm{n}^{\circ} 1$; Perea et al., 2007: 19 ss.; Perea, 2011) o primera mitad del II a. C. (Quesada, 2002-2003: 82, fig. 10; 2016: 168; Mata et al., 2013: 179, fig. 12), se representa una lucha heroica entre un guerrero, ataviado con casco «tipo Montefortino», espada recta y escudo oval, y un monstruo bicéfalo, quizás un lobo. En la parte 
inferior aparece la cabeza de un jabalí y en el puente una sucesión de volutas simula el océano. En las fíbulas de plata de Chiclana de Segura (Jaén) y Cañete de las Torres (Córdoba) (Fig. 16B) también se plasman escenas de caza mítica (Hildebrandt, 1993; AlmagroGorbea y Torres, 1999: 26, 108 y 150-151, lám. 12, no 2-3; Prieto y López, 2000: 44 ss., fig. 5, no 1 y 2a-c; Mata et al., 2013: 175-176, figs. 1 y 6), con jinetes persiguiendo a una cierva y un jabalí. Se vislumbra aquí un trasfondo ideológico autóctono propio de los siglos II-I a. C., coincidente con el de las acuñaciones monetales, interpretándose estas fíbulas como símbolos del estatus ecuestre y síntesis iconográfica de las élites. En esta misma línea, otro evidente paralelismo con el vaso de Lucentum es un pequeño carro votivo de bronce procedente de Mérida (Fig. 16C), en el que un jinete con casco y lanza en ristre, acompañado por un perro, acecha a un jabalí (Blázquez, 1955: 41 ss., figs. 1-4; Almagro-Gorbea, 1977: 251-252, lám. LIII; García-Gelabert y Blázquez, 2006: 106, fig. 22; Jiménez, 2011: 36-37, fig. 1). Su cronología se podría fijar, con reservas, entre los siglos II y I a. C.

Tanto la guerra como la caza en Iberia sirven para ensalzar la memoria de los mejores (optimates) de una comunidad, insertos en un espacio heroico que hunde sus raíces en un pasado mítico muy remoto (Olmos, 2003: 80 y 88; Pérez Blasco, 2014: 774-775). Más que una actividad esencial para la subsistencia, la caza constituye un símbolo de las clases dirigentes. El guerrero, al dominar las armas, otro elemento de prestigio y símbolo de identidad de la aristocracia, y por su destreza montando a caballo, se erige por encima del resto de los ciudadanos (Aranegui, 1998: 176 y 180), pese a no formar parte en el Ibérico Final de unas jefaturas políticamente independientes. Es por ello que cada vez tiene menos sentido representarse con armas, aunque se recurre a éstas en momentos de inestabilidad. En relación con esto último, quizás la aparición de un casco de raigambre itálica en el jinete del vaso lucentino responda a una estrategia para obtener el beneplácito de la autoridad romana.

En las imágenes pintadas sobre la cerámica ibérica parece manifestarse una convivencia, más que un enfrentamiento, entre la naturaleza salvaje (cérvidos, aves, lobos, jabalíes) y la vida doméstica (caballo, perros) (Mata et al., 2013: 188), lectura que encuentra una modesta plasmación en este lágynos. Se busca representar de manera más o menos fiable a los animales, siendo las figuras humanas personajes idealizados (Aranegui, 2000: 298-299). Se recurre además a un repertorio de motivos geométricos y vegetales estilizados y convencionales que articulan el espacio y delimitan las escenas. La apariencia, tamaño y posición de cada elemento en la superficie del vaso sugiere una disposición jerárquica. El friso de los ciervos se concibe como una narración simple desarrollada en una sola secuencia, lo que podría aplicarse también a la escena del jinete, la principal, en la que todos sus integrantes reproducen un mensaje único e independiente. Podrían establecerse incluso tres ámbitos o esferas de la naturaleza fundamentales: el agua, la tierra y el cielo, perfectamente incorporados a los patrones decorativos de la cerámica ibérica de contenido simbólico, y que se traducen en un plano infernal o ctónio, el terrenal y el superior o celeste. Por otra parte, la presencia de estos elementos, más que reiterada en la cerámica ibérica, buscaría quizás la normalización pictórica de una «naturaleza global» más allá de las especies representadas y la adecuada indicación de su propio entorno natural.

Tortosa plantea una cronología entre la segunda mitad del II y el I a. C. para el fragmento del jinete, que clasifica dentro del «grupo sureste II», mientras que la parte del cuello ${ }^{26}$ pertenecería al «estilo I ilicitano», situándolo en la primera mitad del siglo I a. C., datación que consideramos conveniente retrasar algunas décadas atendiendo al contexto en que se produjo el hallazgo. En cuanto a la forma, esta pieza constituye un ejemplo más del proceso de adaptación a los tipos romanos de las cerámicas indígenas, en las que no se prescinde de los esquemas decorativos propios (Ronda y Tendero, 2010: 331).

La conquista romana supuso un cambio trascendental en las sociedades que habitaban estas tierras, sumidas ya en una importante transformación que había arrancado con la venida de los cartagineses en la segunda mitad del siglo III a. C. (Almagro-Gorbea, 2003: 13-15). Este proceso, sin embargo, no se consumará hasta fines del II a. C., con la llegada masiva no sólo de envases anfóricos, vajillas de mesa y nuevos repertorios monetales, sino también con el asentamiento de soldados, mercaderes y colonos itálicos, la práctica de matrimonios mixtos y el reclutamiento de mercenarios. La nueva clientela estimulará tanto la producción como el comercio, de manera que la Contestania se integrará paulatinamente en el seno de las estructuras políticas, económicas y sociales romanas. En este sentido, durante la primera romanización pudieron permitirse y respetarse ciertas tradiciones locales, reduciendo de este modo la conflictividad y el rechazo de los notables indígenas, cuya colaboración para lograr la paz y la progresiva integración del territorio en el nuevo orden jurídico resultaba indispensable (Aranegui, 2007: 180; 2012: 321-322).

A fines del siglo II e inicios del I a. C. se lleva a cabo en el Tossal de Manises una importante intervención edilicia, construyéndose una nueva muralla y reforzándose los accesos (Olcina y Pérez, 1998: 4142; 2003: 94-96; Olcina, 2002: 258 ss.; 2009a: 43-45; Guilabert et al., 2010: 343; Olcina et al., 2014: 128 Ss.). Se erige un primer foro ${ }^{27}$, cuya estructura quedará

26. En el momento de la publicación de su estudio (2006) ambas partes no se encontraban unidas.

27. Sin embargo, no será hasta mediados del I a. C. cuando el recinto adopte un aspecto plenamente romano, coincidiendo con la obtención del estatuto municipal entre los años 30 y 20 a. C., así como con la concesión del rango de colonia 
fosilizada en el de época altoimperial culminado por Tiberio (Olcina et al., 2015b). Curiosamente, durante esta etapa de ocupación romana efectiva se constata la pervivencia de determinados elementos iconográficos de raigambre indígena, coincidiendo en buena medida este resurgir de lo autóctono ${ }^{28}$ con el convulso período de las guerras sertorianas y cesarianas. Las nuevas ciudades romanas debieron atraer a una cierta población de su entorno más inmediato, llegando a ser en ocasiones su componente mayoritario tras abandonar sus asentamientos de origen (Pina, 2011: 47-48).

La reiterada aparición en las decoraciones cerámicas de personajes de origen y aspecto ibérico podría interpretarse, con reservas, como la representación de auxiliares al servicio de las legiones (Paz y Ortiz, 2007: 88-90 y 129-131). Pero más allá de la habitual lectura de estas imágenes en clave reivindicativa y de reafirmación de las señas de identidad de la Cultura Ibérica frente al opresor (Maestro, 2013-14: 72 y 88), el lágynos de Lucentum, elaborado en algún taller del entorno o en la también romana Ilici, debería entenderse como un bien preciado con el que comerciar o quizás un particular obsequio, en todo caso un objeto de prestigio propiedad de un magistrado romano, un miembro de la élite local, de ahí que se vincule a un espacio de singular importancia como es la «domus del peristilo», la residencia de uno de los gobernantes de la ciudad augustea.

\section{REFERENCIAS}

Abad, L. (1986-1987). En torno a dos mosaicos ilicitanos: el «helenístico» y el de conchas marinas. Cuadernos de Prehistoria y Arqueología de la Universidad Autónoma de Madrid, 13-14, 97-105.

Abad, L. y Sanz, R. (1995). La cerámica ibérica con decoración figurada de la provincia de Albacete. Iconografía y territorialidad. Homenaje a la Dra. Milagro Gil-Mascarell. Saguntum, 29, 73-84.

Abascal, J. M. (1986). La cerámica pintada romana de tradición indígena en la Península Ibérica. Centros de producción, comercio y tipología. Madrid.

Abascal, J. M. (2008). Las cerámicas «Tipo Clunia» y otras producciones pintadas hispanorromanas. En D. Bernal y A. Ribera (Eds.). Cerámicas hispanorromanas. Un estado de la cuestión (pp. 429-443). Cádiz: Universidad de Cádiz.

Abascal, J. M. y Alberola, A. (2003). Monedas de época romana. En J. M. Abascal y L. Abad (Eds.). Las ciudades y los campos de Alicante en época romana. Canelobre, 48, 215-221.

a la vecina Ilici (Olcina et al., 2014: 200 ss.; 2015a: 255256; Tendero y Ronda, 2014: 217; Tendero et al., 2014: 232-233).

28. C. Aranegui (2007: nota 4) lo definirá como un «fenómeno de reinvención identitaria».
Abásolo, J. A. y Pérez, F. (1980). El casco céltico de Gorrita (Valladolid). Boletín del Seminario de Estudios de Arte y Arqueología, 46, 93-118.

Alcalá-Zamora, L. (2003). La necrópolis ibérica de Pozo Moro. Bibliotheca Archaeologica Hispana, 23. Madrid: Real Academia de la Historia.

Almagro Basch, M. (1953). Las necrópolis de Ampurias, I. Introducción y necrópolis griegas. Monografías Ampuritanas, III. Barcelona: Seix y Barral.

Almagro-Gorbea, M. (1977). El bronce final y el periodo orientalizante en Extremadura. Bibliotheca Praehistorica Hispana, XIV. Madrid: Consejo Superior de Investigaciones Científicas.

Almagro-Gorbea, M. (1995a) Iconografía numismática hispánica: jinete y cabeza varonil. En La moneda hispánica. Ciudad y territorio (pp. 53-64). Anejos de Archivo Español de Arqueología, XIV. Madrid: Consejo Superior de Investigaciones Científicas.

Almagro-Gorbea, M. (1995b). La moneda hispánica con jinete y cabeza varonil: ¿tradición indígena o creación romana? Zephyrus, XLVIII, 235-266.

Almagro-Gorbea, M. (1996). Lobo y ritos de iniciación en Iberia. En R. Olmos y J. A. Santos (Eds.). Iconografia ibérica, iconografía itálica: propuestas de interpretación (Roma, 2013) (pp. 103-127). Serie Varia, 3. Madrid: Universidad Autónoma de Madrid.

Almagro-Gorbea, M. (1999). El Rey-Lobo de La Alcudia de Elche. En El Rey Lobo de La Alcudia de Elche. (pp. 9-47). Alicante: Universidad de Alicante.

Almagro-Gorbea, M. (2003). La romanización del mundo ibérico del sureste. En J. M. Abascal y L. Abad (Eds.). Las ciudades y los campos de Alicante en época romana. Canelobre, 48, 11-19.

Almagro-Gorbea, M. (2005). Ideología ecuestre en la Hispania prerromana. Gladius, $X X V, 151-186$. DOI: http:// dx.doi.org/10.3989/gladius.2005.27

Aquilué, X., Mar, R., Nolla, J. M., Ruiz de Arbulo, J. y Sanmartí, E. (1984). El fòrum romà d'Empúries (excavacions de l'any 1982). Monografies Emporitanes, VIII. Barcelona: Diputació de Barcelona.

Aquilué, X., Santos, M., Tremoleda, J. y Castanyer, P. (2010). Contextos d'època d'August procedents del fòrum de la ciutat romana d'Empúries. En V. Revilla y M. Roca (Eds.). Contextos ceràmics i cultura material d'època augustal a l'occident romà (Universitat de Barcelona, 2007) (pp. 36-91). Barcelona - Tarragona: Universidad de Barcelona - Institut Català d'Arqueologia Clàssica.

Aranegui, C. (1998). Los iberos a través de sus imágenes. En C. Aranegui (Ed.). Los iberos, príncipes de Occidente. Las estructuras de poder en la sociedad ibérica (Barcelona, 1998) (pp. 174-187). Saguntum extra, 1. Valencia: Universidad de Valencia.

Aranegui, C. (2000). Mostrarse en imágenes. Un recorrido a través de las decoraciones de la cerámica ibérica. En M. Olcina y J. A. Soler (Eds.). Scripta in honorem Enrique A. 
Llobregat Conesa, I (pp. 293-305). Alicante: Museo Arqueológico Provincial de Alicante.

Aranegui, C. (2007). Arte ibérico en la Edetania. En L. Abad y J. A. Soler (Eds.). Arte ibérico en la España Mediterránea (Alicante, 2005) (pp. 167-183). Alicante: Instituto Alicantino de Cultura «Juan Gil Albert».

Aranegui, C. (2012). Los iberos, ayer y hoy. Madrid: Editorial Marcial Pons.

Aranegui, C., Jodin, A., Llobregat, E., Rouillard, P. y Uroz, J. (1993). La nécropole ibérique de Cabezo Lucero (Guardamar del Segura, Alicante). Colección de la Casa de Velázquez, 41. Madrid-Alicante: Casa de Velázquez.

Arévalo, A. (2002-2003). Las imágenes monetales hispánicas como emblemas de Estado. Cuadernos de Prehistoria y Arqueología de la Universidad Autónoma de Madrid, 28-29, 241-258. DOI: http://dx.doi.org/10.15366/ cupauam2003.29.012

Arévalo, A. (2003). La moneda hispánica del jinete ibérico: estado de la cuestión. En F. Quesada y M. Zamora (Eds.). El caballo en la antigua Iberia (pp. 63-74). Madrid: Real Academia de la Historia y Universidad Autónoma de Madrid.

Astruc, M. (1951). La necrópolis de Villaricos. Informes y Memorias de la Comisaría General de Excavaciones Arqueológicas, 25. Madrid: Ministerio de Educación Nacional.

Azuar, R. (1994). El Castillo del Río (Aspe, Alicante). Arqueología de un asentamiento andalusí y la transición al feudalismo (siglos XII-XIII). Alicante: Museo Arqueológico Provincial de Alicante.

Ballester, I., Fletcher, D., Pla, E., Jordá, F. y Alcacer, J. (1954). Corpus Vasorum Hispanorum. Cerámica del Cerro de San Miguel, Liria. Madrid: Consejo Superior de Investigaciones Científicas.

Bayo, S. (2010). El yacimiento ibérico de «El Tossal de la Cala». Nuevo estudio de los materiales depositados en el MARQ correspondientes a las excavaciones de José Belda y Miguel Tarradell. Alicante: Museo Arqueológico de Alicante-MARQ.

Bayo, S. (2014). Identificación del uso del espacio y su momento histórico a partir de los contextos materiales. En F. Sala y J. Moratalla (Eds.). Las guerras civiles romanas en Hispania. Una revisión histórica desde la Contestania (pp. 99-113). Alicante: Museo Arqueológico de Alicante-Universidad de Alicante.

Belda, J. (1953). Museo Arqueológico Provincial de Alicante. Memorias de los Museos Arqueológicos Provinciales, 1950-51, XI-XII. Madrid: Ministerio de Educación Nacional.

Beltrán, M. (1976). Arqueología e historia de las ciudades antiguas del Cabezo de Alcalá de Azaila (Teruel). Monografías arqueológicas, XIX. Zaragoza: Librería General.

Beltrán, M. (1990). Guía de la cerámica romana. Zaragoza: Libros Pórtico.

Beltrán, M. (1996). Los iberos en Aragón. Zaragoza: Caja de Ahorros de la Inmaculada de Aragón.
Blázquez, J. M. (1954). Dioses y caballos en el mundo ibérico. Zephyrus, 5, 193-222.

Blázquez, J. M. (1955). Los carros votivos de Mérida y Almorchón. Zephyrus, 6, 41-560.

Blázquez, J. M. (1959-60). Cascos celtas inéditos. Notas sobre los cascos hispánicos. Boletín de la Comisión Provincial de Monumentos Históricos y Artísticos de Orense, XX, 371-387.

Blech, M. (1996). Los inicios de la iconografía de la escultura ibérica en piedra: Pozo Moro. En R. Olmos y J. A. Santos (Eds.). Iconografía ibérica, iconografía itálica: propuestas de interpretación (Roma, 2013) (pp. 193-210). Serie Varia, 3. Madrid: Universidad Autónoma de Madrid.

Bonet, H. (1995). El Tossal de Sant Miquel de Llíria. La antigua Edeta y su territorio. Valencia: Museo de Prehistoria de Valencia.

Bonet, H. y Ribera, A. (2003). La conquesta romana i el procés de romanització en el món ibèric. En H. Bonet, R. Albiach y M. Gozalbes (Coords.). Romans $i$ visigots a les terres valencianes (pp. 79-90). Valencia: Museo de Prehistoria de Valencia.

Brotons, F. y Ramallo, S. F. (2014). Una dea stephanophoros en el Cerro de los Santos (Montealegre del Castillo, Albacete). En P. Bádenas, P. Cabrera, M. Moreno, A. Ruiz, C. Sánchez y T. Tortosa (Eds.). Per speculum in aenigmate. Miradas sobre la Antigüedad. Homenaje a Ricardo Olmos. Anejos de Erytheia. Estudios y Textos, 7 (pp. 343-349). Madrid: Asociación Cultural Hispano-Helénica.

Cabré, J. (1934). Un pintor ceramista de Azaila que firmó sus principales obras. Anuario del Cuerpo Facultativo de Archiveros, Bibliotecarios y Arqueólogos, 1, 355-382.

Cabré, J. (1944). Corpus Vasorum Hispanorum. Cerámica de Azaila. Museos Arqueológicos de Madrid, Barcelona y Zaragoza. Memorias de la Junta Superior de Excavaciones Arqueológicas, 25. Madrid: Consejo Superior de Investigaciones Científicas.

Cabré, J. y De Motos, F. (1918). La necrópolis ibérica de Tútugi (Galera, Granada). Madrid: Junta Superior de Excavaciones Arqueológicas.

Cabrera, P. (2004a). La cerámica helenística de relieves de La Alcudia (Elche). En T. Tortosa (Coord.). El yacimiento de La Alcudia (Elche, Alicante): pasado y presente de un enclave ibérico (pp. 55-69). Anejos de Archivo Español de Arqueología, XXX. Madrid: Consejo Superior de Investigaciones Científicas.

Cabrera, P. (2004b). Vasos cerámicos de importación de lujo del Mediterráneo oriental y central. En R. Olmos y P. Rouillard (Eds.). La vajilla ibérica en época helenística (siglos IV-III al cambio de Era) (Madrid, 1991) (pp. 5-17). Collection de la Casa de Velázquez, 89. Madrid: Casa de Velázquez.

Cabrera, P. y Pérez, J. (1980). Noticia sobre cerámicas helenísticas de engobe blanco del tipo «lagynos» halladas en Cartagena. Madrider Mitteilungen, 21, 155-164. 
Casas, J., Castanyer, P., Nolla, J. M. y Tremoleda, J. (1990). Ceràmiques comunes $i$ de producción local d'època romana, I. Materials augustals i alto-imperials a les comarques orientals de Girona. Girona: Centre d'Investigacions Arqueològiques de Girona.

Casas, J., Castanyer, P., Nolla, J. M. y Tremoleda, J. (1995). Ceràmiques comunes locals del N. E. de Catalunya. En X. Aquilué y M. Roca (Coords.). Ceràmica comuna romana d'època Alto-Imperial a la Península Ibèrica. Estat de la qüestió (pp. 99-128). Monografies Emporitanes, VIII. Barcelona: Diputació de Barcelona.

Cortell, E., Sala, F., Juan, J., Llobregat, E. A., Reig, C. y Segura, J. M. (1992). La necrópolis ibérica de la Serreta: resumen de la campaña de 1987. En Estudios de Arqueología Ibérica y Romana. Homenaje a Enrique Pla Ballester (pp. 83-116). Trabajos Varios del Servicio de Investigación Prehistórica, 89. Valencia: Servicio de Investigación Prehistórica-Diputación Provincial de Valencia.

Cuadrado, E. (1968). Tumbas principescas de El Cigarralejo. Madrider Mitteilungen, 9, 148-185.

Cuadrado, E. (1982). Decoración extraordinaria de un vaso ibérico. Homenaje a Sáenz de Buruaga (pp. 287-296). Badajoz: Institución Cultural Pedro de Valencia.

Cuadrado, E. (1987). La necrópolis ibérica de «El Cigarralejo» (Mula, Murcia). Bibliotheca Praehistorica Hispana, XXIII. Madrid: Consejo Superior de Investigaciones Científicas.

Chapa, T. (1980). La escultura zoomorfa ibérica en piedra. Madrid.

Chapa, T., Pereira, J., Madrigal, A. y Mayoral, V. (1998). La necrópolis ibérica de Los Castellones de Céal (Hinojares, Jaén). Sevilla: Consejería de Cultura de la Junta de Andalucía-Universidad de Jaén.

Díaz, M. (2000). Tipocronología de los contextos cerámicos tardo-republicanos en Tarraco. Empúries, 52, 201-260.

Domínguez, A. (1998). Las acuñaciones ibéricas y celtibéricas de la Hispania Citerior. Historia monetaria de la Hispania antigua (pp. 116-193). Madrid: Editorial Vico Monteoliva.

Espinosa, A. y Marcos, A. (2014). Los materiales muebles. En P. Rouillard, A. Espinosa y J. Moratalla (Eds.). Villajoyosa Antique (Alicante, Espagne). Territoire et topographie. Le sanctuaire de La Malladeta (pp. 108-155). Collection de la Casa de Velázquez, 141. Madrid: Casa de Velázquez.

Fernández de Avilés, A. (1943). Notas sobre la necrópolis de Archena. Archivo Español de Arqueología, XVI, 115-121.

Fernández de Avilés, A. (1944). Rostros humanos, de frente, en la cerámica ibérica. Ampurias, VI, 161-178.

Fernández Chicarro, C. (1954). Prospección arqueológica en los términos de Hinojares y La Guardia (Jaén). Boletín del Instituto de Estudios Giennenses, VI, 89-102.

Fernández Izquierdo, C. (1980). Estudio de los restos arqueológicos submarinos en las costas de Castellón.
Cuadernos de Prehistoria y Arqueología Castellonenses, 7, 135-195.

Figueras, F. (1940). Datos para la cronología de la cerámica ibérica. Atlantis, $X X V, 177-180$.

Fuentes, M. M. (2006). Propuesta de definición del estilo pictórico de La Serreta (Alcoi, Cocentaina, Penàguila; Alacant). Recerques del Museu d'Alcoi, 15, 29-74.

Fuentes, M. M. (2007). Vasos singulares de la Serreta (Alcoi, Cocentaina, Penàguila; Alacant). Villena: Fundación Municipal «José $\mathrm{M}^{\mathrm{a}}$ Soler».

García y Bellido, A. (1944). Problemas de cronología ibérica. Saitabi, 12, 109-118.

García-Bellido, M. P. y Blázquez, C. (2001a). Diccionario de cecas y pueblos hispánicos, I. Introducción. Colección Textos Universitarios, 35. Madrid: Centro Superior de Investigaciones Científicas.

García-Bellido, M. P. y Blázquez, C. (2001b): Diccionario de cecas y pueblos hispánicos, II. Catálogo de cecas y pueblos que acuñan moneda. Colección Textos Universitarios, 36. Madrid: Centro Superior de Investigaciones Científicas.

García Cardiel, J. (2014). El combate contra el mal: imaginarios locales de poder a través de la conquista romana en el levante ibérico. Complutum, 25 (1), 159-175. DOI: http:// dx.doi.org/10.5209/rev_CMPL.2014.v25.n1.45361

García Hernández, F. (1986). El yacimiento ibérico del Tossal de la Cala (Benidorm). Los materiales depositados en el Museo Arqueológico Provincial de Alicante. (Tesis de Licenciatura inédita). Universidad de Alicante. Alicante.

García Hernández, F. (1987). La cerámica ibérica decorada de estilo Elche-Archena. Alicante.

García Gandía, J. R. (2008). Arqueología en Aspe: poblamiento y territorio. Aspe: Ayuntamiento de Aspe

García-Gelabert, M. P. y Blázquez, J. M. (2006). Dioses y caballos en la Iberia prerromana. Lucentum, $X X V$, 77-123. DOI: http://dx.doi.org/10.14198/LVCENTVM2006.25.06

García-Gelabert, M. P. y Blázquez, J. M. (2007). El significado del ciervo entre los pueblos protohistóricos de la Península Ibérica. Lucentum, XXVI, 83-114. DOI: http:// dx.doi.org/10.14198/LVCENTVM2007.26.04

García Jiménez, G. (2012). El armamento de influencia la Tène en la Península Ibérica (siglos $V$-I a. C.). Monographies Instrumentum, 43. Montagnac: Éditions Monique Mergoil.

García-Mauriño, J. (1993). Los cascos de tipo Montefortino en la Península Ibérica. Aportación al estudio del armamento de la II ${ }^{\mathrm{a}}$ Edad del Hierro. Complutum, 4, 95-146.

González, A. (1975). El yacimiento ibérico del Castillo del Río. Aspe (Alicante). XIII Congreso Nacional de Arqueología (Zaragoza, 1975) (pp. 697-700). Congresos Arqueológicos Nacionales, Secretaría General.

González, J. y Chapa, T. (1993). «Meterse en la boca del lobo». Una aproximación a la figura del «carnassier» en la religión ibérica. Complutum, 4, 169-174. 
Gozalbes, M. (2006). Las emisiones de la Citerior y su vertiente religiosa. X Curs d'Història monetària d'Hispània. Moneda, cultes i ritus (Barcelona, 2006) (pp. 111-130). Barcelona: Museu d'Art de Catalunya.

Grau, I. (1996). Estudio de las excavaciones antiguas de 1953 y 1956 en el poblado ibérico de La Serreta. Recerques del Museu d'Alcoi, 5, 83-120.

Grau, I. (2005). Espacios étnicos y políticos en el área oriental de Iberia. Complutum, 16, 105-123.

Grau, I. (2006). Verlo para creerlo. Reflexiones sobre las imágenes ibéricas de La Serreta. Alcoy. Arqueología y Museo. Museos Municipales en el MARQ (pp. 60-69). Alicante: Museo Arqueológico de Alicante.

Guadán, A. M. de (1979). Las armas en la moneda ibérica. Madrid: Cuadernos de Numismática.

Guadán, A. M. de (1980). La moneda ibérica. Catálogo de numismática ibérica e ibero-romana. Madrid: Cuadernos de Numismática.

Guilabert, A., Moltó, J., Olcina, M. y Tendero, E. (2010). El foro altoimperial de Lucentum. Contextos materiales de su fundación. En V. Revilla y M. Roca (Eds.). Contextos ceràmics $i$ cultura material d'època augustal a l'occident romà (Universitat de Barcelona, 2007) (pp. 342-372). Barcelona - Tarragona: Universidad de Barcelona-Institut Català d'Arqueologia Clàssica.

Hildebrandt, H. J. (1993). Münzenals Hacksilver in Schatzfunden von der iberischen Halbinsel. Madrider Mitteilungen, 24, 161-189.

Huguet, E. y Ribera, A. (2013). Los lagynoi de engobe blanco. En A. Ribera (Coord.). Manual de cerámica romana. Del mundo Helenístico al Imperio Romano (pp. 198-200). Madrid: Museo Arqueológico Regional.

Jiménez, J. (2011). Mérida Pre- y Protohistórica. En J. M. Álvarez y P. Mateos (Eds.): Congreso Internacional. 19102010. El yacimiento emeritense (pp. 35-58). Mérida: Ayuntamiento de Mérida.

Kurtz, W. S. (1992). Guerra y guerreros en la cerámica ibérica. La sociedad ibérica a través de la imagen (pp. 206215). Madrid: Centro Nacional de Exposiciones, Ministerio de Cultura, Dirección General de Bellas Artes y Archivos.

Lafuente, J. (1932). Alicante en la Antigüedad. Alicante: Ayuntamiento de Alicante.

Lafuente, J. (1934). Excavaciones en la Albufereta de Alicante (antigua Lucentum). Junta Superior del Tesoro Artístico, Sección de Excavaciones, 126. Madrid: Junta Superior del Tesoro Artístico.

Lafuente, J. (1944). Algunos datos concretos de la provincia de Alicante sobre el problema cronológico de la cerámica ibérica. Archivo Español de Arqueología, XVII, 68-87.

Lafuente, J. (1957). Alicante en la Edad Antigua. 2a edición aumentada. Alicante.

Lafuente, J. (1959). Museo Arqueológico Provincial de Alicante. Catálogo-guía. Publicaciones del Instituto de
Estudios Alicantinos, XII. Alicante: Instituto de Estudios Alicantinos.

Lara, G. (2007). Nuevos datos para la contextualización del mosaico helenístico de La Alcudia (Elche, Alicante). En L. Abad y J. A. Soler (Eds.). Arte ibérico en la España Mediterránea (Alicante, 2005) (pp. 155-166). Alicante: Instituto Alicantino de Cultura «Juan Gil Albert».

Lenerz-De Wilde, M. (1991). Iberia Celtica. Archäelogische Zeugnisse keltischer Kulturen auf der Pyrenäen halbinsel. Stuttgart: Franz Steiner Verlag.

Llobregat, E. A. (1972). Contestania ibérica. Alicante: Instituto de Estudios Alicantinos.

Llorens, M. M. (1998). La imatge monetària dels pobles ibers de la Citerior. II Curs d'Història monetària d'Hispània. La moneda en la societat ibèrica (Barcelona, 1998) (pp. 4965). Barcelona: Museu d'Art de Calalunya

Maestro, E. M. (1983-84). La figura humana en la cerámica de la provincia de Teruel. Kalathos, 3-4, 111-119.

Maestro, E. M. (1989). Cerámica ibérica decorada con figura humana. Monografías Arqueológicas, 31. Zaragoza: Universidad de Zaragoza.

Maestro, E. M. (2010). Las armas en la cerámica ibérica aragonesa. Gladius, $X X X, 213-240$. DOI: http://dx.doi. org/10.3989/gladius.2010.0011

Maestro, E. M. (2013). Escenas y protagonistas de la cerámica ibérica aragonesa. Saldvie, 13-14, 71-91.

Maluquer, J. (1987). Un casco ibérico probablemente de la necrópolis de Galera (Granada) en el Instituto de Arqueología de la Universidad de Barcelona. Homenaje a D. Domingo Fletcher Valls, Archivo de Prehistoria Levantina, XVII, 257-260.

Marín, M. C. (2000-2001). La representación de los dioses en el mundo ibérico. Lucentum, XIX-XX, 183-198. DOI: http:// dx.doi.org/10.14198/LVCENTVM2000-2001.19-20.11

Mata, C. y Bonet, M. (1992). La cerámica ibérica: ensayo de tipología. En Estudios de Arqueología Ibérica y Romana. Homenaje a Enrique Pla Ballester (pp. 117-173). Trabajos Varios del Servicio de Investigación Prehistórica, 89. Valencia: Servicio de Investigación Prehistórica-Diputación Provincial de Valencia.

Mata, C., Badal, E., Collado, E. y Ripollès, P. P. (Eds.). (2010). Flora ibérica. De lo real a lo imaginario. Trabajos Varios del Servicio de Investigación Prehistórica, 111. Valencia: Servicio de Investigación Prehistórica-Diputación Provincial de Valencia.

Mata, C. y Soria, L. (2012). ¡Qué viene el lobo! De lo real a lo imaginario: aproximación a la fauna ibérica de la Edad del hierro. En M. R. Huerta y F. Ruiz (Dirs.). Animales simbólicos en la Historia. Desde la Protohistoria hasta el final de la Edad Media (pp. 47-78). Madrid: Síntesis.

Mata, C., Bonet, H., Collado, E., Fuentes, M. M., Izquierdo, M. I., Moreno, A.,... y Tormo, C. (2013). Fíbulas y género: de animales y hombres en la Cultura Ibérica. Zephyrus, LXXI, 173-195. 
Mata, C. (Coord.). (2014). Fauna ibérica. De lo real a lo imaginario (II). Trabajos del Servicio de Investigación Prehistórica, 117. Valencia: Servicio de Investigación Prehistórica-Diputación Provincial de Valencia.

Mazzoli, M. (2016). Elmi «Montefortino» nel Mediterraneo Occidentale. En R. Graells y D. Mazzoli (Eds.). Armamento y arqueología de la guerra en la Península Ibérica prerromana (s. VI-I a. C.): problemas, objetivos y estrategias. Armas de la Hispania prerromana (pp. 109-148). Mainz: Römisch-Germanischen Zentralmuseums.

Moratalla, J. (2015). Aspe en el territorio ibérico contestano: luces y sombras de un proceso histórico. En M. T. Berná y F. F. Tordera (Coords.). Aspe a la luz de la Arqueología (pp. 113-119). Aspe: Ayuntamiento de Aspe.

Moret, P., Benavente, J. A., Melguizo, S. y Marco, F. (2012). El oppidum de El Palao (Alcañiz, Teruel): balance de diez años de investigación (2003-2012). En M. C. Belarte, J. A. Benavente, L. Fatás, J. Diloli, P. Moret y J. Noguera (Eds.). II Congreso Internacional. Iberos del Ebro (Alcañiz-Tivissa, 2011) (pp. 195-210). Documenta, 25. Tarragona: Institut Català d'Arqueologia Clàssica.

Nieto, G. (1939-1940). Noticia de las excavaciones realizadas en la necrópolis hispánica del Cabecico del Tesoro, Verdolay (Murcia). Boletín del Seminario de Estudios de Arte y Arqueología, 6, 137-160.

Nieto, G. (1944). La necrópolis hispánica del Cabecico del Tesoro. Verdolay (Murcia) (IV Campaña de Excavaciones). Boletín del Seminario de Estudios de Arte y Arqueología, $\mathrm{X}, 165-175$.

Nordström, S. (1967). Excavaciones en el poblado ibérico de La Escuera (San Fulgencio, Alicante). Trabajos Varios del Servicio de Investigación Prehistórica, 34. Valencia: Servicio de Investigación Prehistórica-Diputación Provincial de Valencia.

Nordström, S. (1968). Representaciones de aves en la cerámica ibérica del sureste de España. Opuscula Romana, VI, 97-120.

Nordström, S. (1973). La céramique peinte ibérique de la province d'Alicante, II. Acta Universitatis Stockholmiensis, VIII. Estocolmo.

Olcina, M. H. (2002). Lucentum. En J. L. Jiménez y A. Ribera (Coords.). Valencia y las primeras ciudades romanas de Hispania (pp. 255-266). Valencia: Ayuntamiento de Valencia.

Olcina, M. H. (2007a). Jarro. Guía-catálogo del Museo Arqueológico de Alicante. Alicante: Museo Arqueológico de Alicante.

Olcina, M. H. (2007b). La cultura ibérica en la exposición permanente del MARQ. En L. Abad y J. Soler (Eds.). Arte ibérico en la España Mediterránea (Alicante, 2005) (pp. 83-102). Alicante: Instituto Alicantino de Cultura «Juan Gil Albert».

Olcina, M. H. (2009a). Evolución histórica y urbana. En M. Olcina (Ed.). Lucentum (Tossal de Manises, Alicante). Arqueología e Historia (pp. 33-63). Alicante: Museo Arqueológico de Alicante.
Olcina, M. H. (2009b). Las construcciones de la ciudad antigua. En M. Olcina (Ed.). Lucentum (Tossal de Manises, Alicante). Arqueología e Historia. (pp. 65-113). Alicante: Museo Arqueológico de Alicante.

Olcina, M. H. y Pérez, R. (1998). La ciudad ibero-romana de Lucentum (El Tossal de Manises, Alicante). Introducción a la investigación del yacimiento arqueológico y su recuperación como espacio público. Alicante: Museo Arqueológico Provincial de Alicante.

Olcina, M. H. y Pérez, R. (2003). Lucentum: la ciudad y su entorno. En J. M. Abascal y L. Abad (Eds.). Las ciudades y los campos de Alicante en época romana. Canelobre, 48, 91-119.

Olcina, M. H. y Pérez, R. (2009). Historia de la investigación y de la recuperación del yacimiento. En M. Olcina (Ed.). Lucentum (Tossal de Manises, Alicante). Arqueología e Historia (pp. 21-31). Alicante: Museo Arqueológico de Alicante.

Olcina, M., Guilabert, A. y Tendero, E. (2010). Lectura púnica del Tossal de Manises (Alicante). En E. Ferrer (Coord.). Los púnicos de Iberia: proyectos, revisiones, sintesis. Mainake, XXXII (1), 127-137.

Olcina, M., Guilabert, A. y Tendero, E. (2014). Fortificaciones tardorrepublicanas de Lucentum (Hispania Citerior). En F. Sala y J. Moratalla (Eds.). Las guerras civiles romanas en Hispania. Una revisión histórica desde la Contestania (pp. 127-137). Alicante: Museo Arqueológico de Alicante-Universidad de Alicante.

Olcina, M., Guilabert, A. y Tendero, E. (2015a). Lucentum: el paisaje urbano augusteo. En J. López (Ed.). $2^{\text {on }}$ Congrés Internacional d'Arqueologia i Món Antic. August i les províncies occidentals. 2000 aniversari de la mort d'August (Tarragona, 2014), I (pp. 255-261). Tarragona: Institut Català d'Arqueologia Clàssica.

Olcina, M., Guilabert, A. y Tendero, E. (2015b). El foro de Lucentum (Tossal de Manises, Alicante). Conventus Carthaginensis-Hispania Tarraconensis. En J. M. Àlvarez, T. Nogales e I. Rodà (Eds.). XVIII Congreso Internacional de Arqueología Clásica. Centro y periferia en el mundo clásico, I (pp. 825-830). Mérida: Museo Nacional de Arte Romano.

Olcina, M. H., Guilabert, A., Tendero, E. y Pérez, R. (2014). Lucentum. En M. Olcina (Ed.). Ciudades romanas valencianas. Actualidad de la investigación historicoarqueológica (MARQ, 2013) (pp. 199-223). Alicante: Museo Arqueológico de Alicante.

Oliver, A. (1987-1988). Tres yelmos tipo Monteforfino hallados en Benicarló (Castellón). Cuadernos de Prehistoria y Arqueología Castellonenses, 13, 205-212.

Olmos, R. (1987). Posibles vasos de encargo en la cerámica ibérica del sureste. Archivo Español de Arqueología, 60, 21-42.

Olmos, R. (1988-89). Originalidad y estímulos mediterráneos en la cerámica ibérica: el ejemplo de Elche. Lucentum, VII-VIII, 79-102. DOI: http://dx.doi.org/10.14198/ LVCENTVM1988-1989.7-8.04 
Olmos, R. (1992). El rostro del otro. Sobre la imagen frontal de la divinidad en la cerámica de Elche. Archivo Español de Arqueología, 65, 304-308.

Olmos, R. (2000). Recuerdo heroico y realidad anticipada en la imagen ibérica. En M. Olcina y J. A. Soler (Eds.). Scripta in honorem Enrique A. Llobregat Conesa, I (pp. 349-355). Alicante: Museo Arqueológico Provincial de Alicante.

Olmos, R. (2001-2002). Concordia y violencia en la naturaleza ibérica. Un esbozo sobre percepciones. En Soliferrum. Studia archaeologica et historica Emeterio Cuadrado Díaz ab amicis, collegis et discipulis dicata. Anales de Prehistoria y Arqueología, 17-18, 205-214.

Olmos, R. (2003). Combates singulares: lenguajes de afirmación de Iberia frente a Roma. En T. Tortosa y J. A. Santos (Eds.). Arqueología e iconografía. Indagar en las imágenes (Roma, 2001) (pp. 79-97). Roma: L'Erma di Bretschneider.

Olmos, R. y Grau, I. (2005). El Vas dels Guerrers de La Serreta. Recerques de Museu d'Alcoi, 14, 79-98.

Page, V. (1984). Imitaciones de influjo griego en la cerámica ibérica de Valencia, Alicante y Murcia. Iberia Graeca. Serie Arqueológica, 1. Madrid: Consejo Superior de Investigaciones Científicas.

Pastor, J. M. (1998). Ideogramas musicales, onomatopéyicos y animistas de las pinturas figurativas ibéricas y celtibéricas. Kalathos, 17, 91-129.

Pastor, J. M. (2010): Doble espiral y eses en serie: símbolos gráficos de «cadencia» en las culturas ibérica y celtibérica. En F. Burillo (Coord.). VI Simposio sobre Celtíberos. Ritos y mitos (Zaragoza, 2008) (pp. 473-484). Zaragoza: Fundación Segeda-Centro de Estudios Celtibéricos de Segeda.

Paz, J. Á. y Ortiz, M. E. (2007). El jinete en la moneda ibérica y celtibérica. Su imagen e interpretación: un arte provincial romano. Numisma, 251, 87-136.

Pellicer, M. (1970): La cerámica ibérica del Cabezo de Azaila. Caesaraugusta, 33-34, 63-87

Perea, A. (Ed.) (2011). La fibula Braganza. The Braganza Brooch. Madrid: Consejo Superior de Investigaciones Científicas.

Perea, A., Williams, D. y Olmos, R. (2007). El héroe y el monstruo. Madrid: Museo Arqueológico Nacional.

Pérez Ballester, J. (1985). Testimonio de tráfico marítimo con el Mediterráneo oriental en Cartagena. En Ceràmiques gregues $i$ helenístiques a la Península Ibèrica (Empúries, 1983) (pp. 143-150). Monografies Emporitanes, VII. Barcelona: Diputació de Barcelona.

Pérez Ballester, J. (1994). Asociaciones de laginos, boles helenísticos de relieves y ánforas rodias en contextos mediterráneos (siglos II y I a. C.). En P. Cabrera, R. Olmos y E. Sanmartí (Eds.). Iberos y griegos: lecturas desde la diversidad (Ampurias, 1991). Huelva Arqueológica, XIII, 2, 345-365.

Pérez Ballester, J. (2012). Sobre cerámicas helenísticas en Iberia/Hispania. Significado y funcionalidad.
Archivo Español de Arqueología, 85, 65-78. DOI: http:/ dx.doi.org/10.3989/aespa.085.012.004

Pérez, J. y Mata, C. (1998). Los motivos vegetales en la cerámica del Tossal de Sant Miquel (Llíria, València). Función y significado en los Estilos I y II. En C. Aranegui (Ed.). Los iberos, príncipes de Occidente. Las estructuras de poder en la sociedad ibérica (Barcelona, 1998) (pp. 231-243). Saguntum extra, 1. Valencia: Universidad de Valencia.

Pérez Blasco, M. F. (2012). El kalathos del gallo: una decoración simbólica singular en un vaso de Lucentum. MARQ, Arqueología y Museos, 5, 133-153.

Pérez Blasco, M. F. (2014). Cerámicas ibéricas figuradas (siglos V-I a. C.). Iconografía e iconología. (Tesis doctoral). Universidad de Alicante. Alicante. Recuperado de: http:// rua.ua.es/dspace/handle/10045/41124

Pérez Burgos, J. M. (1994). Memoria preliminar sobre la excavación arqueológica llevada a cabo por el COPHIAM en la calle Rómulo (Albufereta, Alicante). LQNT, 2, 45-68.

Pericot, L. (1979). Cerámica ibérica. Barcelona: Ediciones Polígrafa S.A.

Pierobon-Benoit, R. (1979). Lagynos: funzione e forma. $R i$ vista di Studi Liguri, XLV, 27-50.

Pina, F. (2011). Etnia, ciudad y provincia en la Hispania republicana. En A. Caballos y S. Lefebvre (Eds.). Roma generadora de identidades. La experiencia hispana (pp. 39-53). Madrid: Casa de Velázquez.

Poveda, A. M. (1988). El poblado Ibero-Romano de «El Monastil» (Elda, Alicante). Introducción Histórico-Arqueológica. Elda: Ayuntamiento de Elda.

Poveda, A. M. y Uroz, H. (2007). Iconografía vascular en El Monastil. En L. Abad y J. Soler (Eds.). Arte ibérico en la España Mediterránea (Alicante, 2005) (pp. 125-139). Alicante: Instituto Alicantino de Cultura «Juan Gil Albert».

Prieto, S. y López, V. M. (2000). Fíbulas argénteas con escena figurada de la Península Ibérica. Complutum, 11, 41-62.

Principal, J. (2008). El Mediterráneo Occidental como espacio periférico de imitaciones. En D. Bernal y A. Ribera (Eds.). Cerámicas hispanorromanas. Un estado de la cuestión (pp. 127-146). Cádiz: Universidad de Cádiz.

Py, M. (1993). Céramique à pâte claire récente. Lattara, 6 , 222-243.

Quesada, F. (1986-1987). El armamento de la necrópolis ibérica de «El Cabecico del Tesoro» (Murcia). Homenaje al Prof. Gratiniano Nieto, II. Cuadernos de Prehistoria y Arqueología de la Universidad Autónoma de Madrid, 1314, 47-63.

Quesada, F. (1989). Armamento, guerra y sociedad en la necrópolis ibérica de "El Cabecico del Tesoro» (Murcia, España). BAR International Series, 502. Óxford: British Archaeological Reports.

Quesada, F. (1990). Armamento de supuesta procedencia meseteña en las necrópolis ibéricas de Murcia. En II Simposio sobre los celtíberos. Necrópolis celtibéricas (Daroca, 
1988) (pp. 231-240). Zaragoza: Institución Fernando el Católico.

Quesada, F. (1992). El casco de Almaciles (Granada) y la cuestión de los cascos de tipo Montefortino en la Península Ibérica. Verdolay, 4, 65-73.

Quesada, F. (1997). El armamento ibérico. Estudio tipológico, geográfico, funcional, social y simbólico de las armas en la Cultura Ibérica (siglos VI-I a. C.). Montagnac: Éditions Monique Mergoil.

Quesada, F. (1998). Aristócratas a caballo y la existencia de una verdadera «caballería» en la cultura ibérica: dos ámbitos conceptuales diferentes. En C. Aranegui (Ed.). Los iberos, principes de Occidente. Las estructuras de poder en la sociedad ibérica (Barcelona, 1998) (pp. 169-183). Saguntum extra, 1. Valencia: Universidad de Valencia.

Quesada, F. (2002-2003). Innovaciones de raíz helenística en el armamento y tácticas de los pueblos ibéricos desde el siglo III a. C. Cuadernos de Prehistoria y Arqueología de la Universidad Autónoma de Madrid, 28-29, 69-94. DOI: http://dx.doi.org/10.15366/cupauam2003.29.005

Quesada, F. (2006). Armamento indígena y romano republicano en Iberia (siglos III-I a. C.): compatibilidad y abastecimiento de las legiones republicanas en campaña. En Á. Morillo (Ed.). Arqueología militar romana en Hispania, II. Producción y abastecimiento en el ámbito militar (pp. 7596). León: Universidad de León-Ayuntamiento de Léon.

Quesada, F. (2008). Armas de Grecia y Roma. Forjaron la historia de la Antigüedad clásica. Madrid: La Esfera de los Libros.

Quesada, F. (2010). Armas de la antigua Iberia. De Tartesos a Numancia. Madrid: La Esfera de los Libros.

Quesada, F. (2016). La guerra y el armamento ibérico: estado actual. En R. Graells y D. Marzoli (Eds.). Armamento y arqueología de la guerra en la Península Ibérica prerromana (s. VI-I a. C.): problemas, objetivos y estrategias. Armas de la Hispania prerromana (pp. 165-337). Mainz: RömischGermanischen Zentralmuseums.

Ramos Fernández, R. (1982). Precisiones para la clasificación de la cerámica ibérica. Lucentum, I, 117-133. DOI: http://dx.doi.org/10.14198/LVCENTVM1982.1.05

Ramos Fernández, R. (1991). Simbología de la cerámica ibérica de La Alcudia de Elche. Elche: Museo Monográfico de la Alcudia.

Ramos Fernández, R. (1992). La crátera iberorromana de La Alcudia. En Estudios de Arqueología Ibérica y Romana. Homenaje a Enrique Pla Ballester (pp. 175-189). Trabajos Varios del Servicio de Investigación Prehistórica, 89. Valencia: Servicio de Investigación Prehistórica-Diputación Provincial de Valencia.

Ramos Fernández, R. (1992-1994). Sobre dos fragmentos cerámicos ibéricos de La Alcudia decorados con rostros frontales. Lucentum, XI-XIII, 127-130. DOI: http://dx.doi. org/10.14198/LVCENTVM1992-1994.11-13.09

Ramos Folqués, A. (1961). Los jinetes con lanza en la cerámica pintada de la Alcudia de Elche. En VI Congreso
Arqueológico Nacional (Oviedo, 1959) (pp. 170-172). Zaragoza: Universidad de Zaragoza.

Ramos Folqués, A. (1975). Un mosaico helenístico en La Alcudia de Elche. Archivo de Prehistoria Levantina, XIV, 69-81.

Ramos Folqués, A. (1990). Cerámica ibérica de La Alcudia (Elche, Alicante). Alicante: Instituto de Cultura «Juan Gil Albert».

Reig, C. (2000). El armamento de la necrópolis ibérica de La Serreta. Gladius, 20, 75-117. DOI: http://dx.doi. org/10.3989/gladius.2000.65

Ribera, A. (2014). La destrucción de Valentia (75 a.C.) y la cultura material de la época de Sertorio. En F. Sala y J. Moratalla (Eds.). Las guerras civiles romanas en Hispania. Una revisión histórica desde la Contestania (pp. 65-77). Alicante: Museo Arqueológico de Alicante-Universidad de Alicante.

Ripollès, P. P. y Abascal, J. M. (2000). Monedas hispánicas. Catálogo del Gabinete de Antigüedades. Madrid: Real Academia de la Historia.

Ronda, A. M. y Tendero, M. (2010). Los materiales de época augustea en Ilici (La Alcudia, Elche). En V. Revilla y M. Roca (Eds.). Contextos cerámicos y cultura material de época augustea en el occidente romano (pp. 322-341). Barcelona-Tarragona: Universitat de Barcelona-Institut Català d'Arqueologia Clàssica.

Ronda, A. M. y Tendero, M. (2014). Producciones locales de época augustea de Ilici: las imitaciones de paredes finas y de la vajilla metálica romana. En R. Morais, A. Fernández y M. J. Sousa (Eds.). As produções cerámicas de imitação na Hispania, I (pp. 191-213). Porto: Faculdade de Letras da Universidade do Porto-Sociedad de Estudios de la Cerámica Antigua en Hispania.

Ronda, A. M. y Tendero, M. (2015). La reinterpretación de un depósito augusteo: el cantharus de Ilici. En J. López (Ed.). $2^{\text {on }}$ Congrés Internacional d'Arqueologia i Món Antic. August $i$ les províncies occidentals. 2000 aniversari de la mort d'August (Tarragona, 2014), I (pp. 263-268). Tarragona: Institut Català d'Arqueologia Clàssica.

Ros, M. M. (1989). La pervivencia del elemento indígena: la cerámica ibérica. La ciudad romana de Carthago Nova: fuentes y materiales para su estudio, 1. Murcia: Universidad de Murcia.

Rosser, P. (1990-1991). La necrópolis romana alto-imperial del «Parque de las Naciones» (Albufereta, Alicante): estudio de alguno de sus materiales. Lucentum, $I X-X$, 85-101. DOI: http://dx.doi.org/10.14198/LVCENTVM1990-1991.9-10.05

Rosser, P. y Fuentes, C. (2007). Tossal de les Basses. Seis mil años de historia de Alicante. Alicante: Ayuntamiento de Alicante.

Rosser, P. y Soler, S. (2014). El mito del héroe en una necrópolis periurbana tardo-republicana, en un asentamiento del Mediterráneo Occidental (Alicante, España). Revista Electrónica Historias del Orbis Terrarum, 12, 69-127. Recuperado de: http://www.orbisterrarum.cl 
Russell, H. (1975). The armour of Imperial Rome. Londres: Arms and Armour Press.

Sala, F. (1992). La «tienda del alfarero» del yacimiento ibérico de La Alcudia. Alicante: CAM-Fundación Cultural.

Sala, F., Moltó, J., Olcina, M. y Guilabert, A. (2007). Las imitaciones de vajilla de mesa de los siglos I a.C. y I d.C. del sector BC de Lucentum. En M. Roca y J. Principal (Eds.). Les imitacions de vaixella fina importada a la Hispania $\mathrm{C} i$ terior (segles I aC-I $d C$ ) (pp. 133-149). Documenta, 6. Tarragona: Institut Català d'Arqueologia Clàssica.

Sala, F., Bayo, S. y Moratalla, J. (2013). Dianium, Sertorio y los piratas cilicios. Conquista y romanización de la Contestania. En A. Álvarez-Ossorio, E. Ferrer y E. García (Coords.). Piratería y seguridad maritima en el Mediterráneo antiguo (pp. 187-210). Spal Monografías, XVII. Sevilla: Universidad de Sevilla.

Sánchez, J. (1943). Memoria de los trabajos realizados por la Comisaría Provincial de Excavaciones Arqueológicas de Albacete en 1941. Informes y memorias de la Comisaría General de Excavaciones Arqueológicas, 3. Madrid: Ministerio de Educación Nacional.

Santos, J. A. (2004). Iconografía y cambio social: la imagen ibérica en Elche y su entorno. En T. Tortosa (Coord.). El yacimiento de La Alcudia (Elche, Alicante): pasado y presente de un enclave ibérico (pp. 223-244). Anejos de Archivo Español de Arqueología, XXX. Madrid: Consejo Superior de Investigaciones Científicas.

Santos, J. A. (2010). Naturaleza y abstracción en la cerámica ibérica con decoración pintada figurada. Complutum, 21 (1), 145-168.

Sanz, R. (1997). Cultura ibérica y romanización en tierras de Albacete: los siglos de transición. Albacete: Instituto de Estudios Albacetenses.

Siret, L. (1906). Villaricos y Herrerías. Antigüedades púnicas, romanas, visigóticas y árabes. Memoria descriptiva e histórica. Madrid: Real Academia de la Historia.

Stary, P. F. (1982). Keltische Waffenauf der Iberischen Halbinsel. Madrider Mitteilungen, 23, 114-144.

Tendero, M. y Ronda, A. M. (2014). Ilici en las guerras civiles romanas. En F. Sala y J. Moratalla (Eds.). Las guerras civiles romanas en Hispania. Una revisión histórica desde la Contestania (pp. 217-227). Alicante: Museo Arqueológico de Alicante-Universidad de Alicante.

Tendero, M., Ronda, A. M., Ramos, R., Ramos, A., Peña, P. y Abad, L. (2014). Ilici. En M. Olcina (Ed.). Ciudades romanas valencianas. Actualidad de la investigación historicoarqueológica (MARQ, 2013) (pp. 225-249). Alicante: Museo Arqueológico de Alicante.

Tiemblo, A. (1997). Rostros frontales en el arte ibérico. Los ejemplares de Hellín y el Tolmo de Minateda. Revista de Arqueología, 191, 12-17.

Tiemblo, A. (1999). Iconografía del rostro frontal en la cerámica ibérica. Complutum, 10, 175-194.
Tortosa, T. (1996). Los signos vegetales en la cerámica ibérica de la zona alicantina. En R. Olmos y J. A. Santos (Eds.). Iconografía ibérica, iconografia itálica: propuestas de interpretación (Roma, 2013) (pp. 177-191). Serie Varia, 3. Madrid: Universidad Autónoma de Madrid.

Tortosa, T. (1998). Los grupos pictóricos en la cerámica del sureste y su vinculación al denominado estilo Elche-Archena. En C. Aranegui (Ed.). Los iberos, príncipes de Occidente. Las estructuras de poder en la sociedad ibérica (Barcelona, 1998) (pp. 207-216). Saguntum extra, 1. Valencia: Universidad de Valencia.

Tortosa, T. (2004a). Tipología e iconografía de la cerámica ibérica figurada en el enclave de La Alcudia (Elche, Alicante). En T. Tortosa (Coord.). El yacimiento de La Alcudia (Elche, Alicante): pasado y presente de un enclave ibérico (pp. 71-222). Anejos de Archivo Español de Arqueología, XXX. Madrid: Consejo Superior de Investigaciones Científicas.

Tortosa, T. (2004b). La «vajilla» ibérica de La Alcudia (Elche, Alicante) en el contexto vascular del Sureste peninsular. En R. Olmos y P. Rouillard (Eds.). La vajilla ibérica en época helenística (siglos IV-III al cambio de Era) (Madrid, 1991) (pp. 97-111). Collection de la Casa de Velázquez, 89. Madrid: Casa de Velázquez.

Tortosa, T. (2006). Los estilos y grupos pictóricos de la cerámica ibérica figurada de la Contestania. Anejos de Archivo Español de Arqueología, XXXVIII. Mérida: Consejo Superior de Investigaciones Científicas.

Uroz, H. (2008). Los iberos de Elda. El poder de las imágenes, las imágenes del poder. Elda. Arqueología y Museo. Museos Municipales en el MARQ (pp. 60-77). Alicante: Museo Arqueológico de Alicante.

Uroz, H. (2012). Prácticas rituales, iconografia vascular y cultura material en Libisosa (Lezuza, Albacete). Nuevas aportaciones al Ibérico Final del Sudeste. Alicante: Universidad de Alicante.

Uroz, H. (2013). Héroes, guerreros, caballeros, oligarcas: tres nuevos vasos singulares ibéricos procedentes de Libisosa. Archivo Español de Arqueología, 86, 51-73. DOI: http:// dx.doi.org/10.3989/aespa.086.013.004

Uroz, H. y Uroz, J. (2014). La Libisosa iberorromana: un contexto cerrado de -y por- las guerras sertorianas. En F. Sala y J. Moratalla (Eds.). Las guerras civiles romanas en Hispania. Una revisión histórica desde la Contestania (pp. 199-215). Alicante: Museo Arqueológico de Alicante-Universidad de Alicante.

Verdú, E. (2007). Oinokhóe ibérico pintado. Del Mediterráneo a los Andes (pp. 70-71). Alicante: CAM.

Verdú, E. (2009). El jinete y el monstruo. Un oinokhóe ibérico decorado de Ifach. Calp. Arqueología y Museo. Museos Municipales en el MARQ (pp. 68-83). Alicante: Museo Arqueológico de Alicante.

Verdú, E. (2015). La necrópolis ibérica de l'Albufereta (Alacant). Ritos y usos funerarios en un contexto de interacción cultural. Serie Mayor, 11. Alicante: Museo Arqueológico de Alicante. 
Verdú, E. y Olcina, M. H. (2012). Un fragmento de cerámica ibérica pintada del Tossal de Manises atribuido a Castillo del Río (Aspe). MARQ, Arqueología y Museos, 5, 155-164.

Vegas, M. (1973). Cerámica común romana del Mediterráneo occidental. Barcelona: Universidad de Barcelona.

Villaronga, L. (1994). Corpus nummum Hispaniae ante Augusti aetatem. Madrid: José A. Herrero D.L.
Villaronga, L. (1995). Denarios y quinarios ibéricos. Estudio y catalogación. Barcelona-Madrid: Asociación Numismática Española-Museo Casa de la Moneda.

Vives, A. (1924). La moneda hispánica, II. Madrid: Real Academia de la Historia.

VV.AA. (2004). Scombraria. La historia oculta bajo el mar. Arqueología submarina en Escombreras, Cartagena. Murcia: Comunidad Autónoma de la Región de Murcia. 